Article

\title{
Integrated Deep Renovation of Existing Buildings with Prefabricated Shell Exoskeleton
}

\author{
Jacopo Zanni ${ }^{1}$, Stefano Cademartori ${ }^{1}$, Alessandra Marini ${ }^{1, *}$, Andrea Belleri ${ }^{1}$, Chiara Passoni ${ }^{1}$ (D), Ezio Giuriani ${ }^{2}$, \\ Paolo Riva ${ }^{1}\left(\mathbb{D}\right.$, Barbara Angi ${ }^{2} \mathbb{D}$, Giovanni Brumana ${ }^{1}$ and Angelo Luigi Marchetti ${ }^{3}$ (D)
}

1 Department of Engineering and Applied Sciences, University of Bergamo, 24044 Dalmine, BG, Italy; jacopo.zanni@unibg.it (J.Z.); stefano.cademartori@unibg.it (S.C.); andrea.belleri@unibg.it (A.B.); chiara.passoni@unibg.it (C.P.); paolo.riva@unibg.it (P.R.); giovanni.brumana@unibg.it (G.B.)

2 Dipartimento di Ingegneria Civile, Architettura, Territorio e Ambiente e di Matematica, Università degli Studi di Brescia, 25123 Brescia, BS, Italy; ezio.giuriani@unibs.it (E.G.); barbara.angi@unibs.it (B.A.)

3 Marlegno S.r.l., 24060 Bolgare, BG, Italy; marchetti.angelo@marlegno.it

* Correspondence: alessandra.marini@unibg.it

\section{check for} updates

Citation: Zanni, J.; Cademartori, S. Marini, A.; Belleri, A.; Passoni, C. Giuriani, E.; Riva, P.; Angi, B.; Brumana, G.; Marchetti, A.L. Integrated Deep Renovation of Existing Buildings with Prefabricated Shell Exoskeleton. Sustainability 2021, 13, 11287. https://doi.org/10.3390/ su132011287

Academic Editors: Maria Rosa Valluzzi and Angelo Masi

Received: 27 July 2021

Accepted: 8 October 2021

Published: 13 October 2021

Publisher's Note: MDPI stays neutral with regard to jurisdictional claims in published maps and institutional affiliations.

Copyright: (c) 2021 by the authors. Licensee MDPI, Basel, Switzerland This article is an open access article distributed under the terms and conditions of the Creative Commons Attribution (CC BY) license (https:// creativecommons.org/licenses/by/ $4.0 /)$.
Abstract: The European goal to reach carbon neutrality in 2050 has further put the focus on the construction sector, which is responsible for great impacts on the environment, and new sustainable solutions to renovate the existing building stock are currently under development. In this paper, the AdESA (Adeguamento Energetico Sismico ed Architettonico, in Italian) system, a holistic retrofit technique for the integrated renovation of the existing buildings, is presented. The system was developed by a consortium of enterprises and universities and was applied to a pilot building. The system consists of a dry, modular and flexible shell exoskeleton technique that implements different layers depending on the building retrofit needs (cross-laminated timber (CLT) panels for the structural retrofit, thermal insulation panels for the energy efficiency amelioration, and claddings for the architectural restyling). In order to foster actual sustainability, the solution contextually targets eco-efficiency, safety and resilience. To this end, the system not only couples the structural and energy interventions to reduce the operating costs, but it is also conceived in compliance with life cycle thinking (LCT) principles to reduce impacts throughout the remaining building service life (from retrofit time to the end of its life). The system is designed to be easily mountable and demountable to allow for the reuse/recycling of its components at the end of life by adopting macro-prefabricated dry components and standardized connections, to reduce damage caused by earthquakes by reducing the allowed inter-story drift, and by amassing the possible damage into sacrificial replaceable elements. The paper describes the AdESA system from a multidisciplinary perspective and its effective application for the deep renovation of an existing gymnasium hall.

Keywords: life cycle thinking (LCT); holistic renovation; deep renovation; cross-laminated timber (CLT) prefabricated shell exoskeleton; AdESA system; case study

\section{Introduction and Research Motivation}

The construction sector is of strategic importance for the European Union, generating almost $9 \%$ of the gross domestic product (GDP) in the EU and providing 18 million direct jobs [1]. However, it is also one of the highest impacting sectors from an environmental point of view, being responsible for about $50 \%$ of the raw material depletion, $35 \%$ of waste production, 35\% of energy consumption, and 36\% of greenhouse gas (GHG) emissions [2].

In the last few decades, the major efforts to reduce the impacts of the construction sector have been mainly dedicated to the reduction of energy consumption and $\mathrm{CO}_{2}$ emissions during building use (i.e., for heating, cooling, and hot water production). A BPIE report [3] shows that, in order to reach the goal of a climate-neutral Europe by 2050, the emissions of buildings should be cut by $60 \%$ by 2030 . Considering that the existing building 
stock is expected to represent $85 \%$ of the 2050 stock, this target may only be reached by increasing the average rate of deep renovation (i.e., a renovation that reduces the GHG emissions by $60 \%$ ) from the actual $1 \%$ to $4.4 \%$ in the decade from 2020 to 2030.

In addition, even if this ambitious target were met, this would solve just one of the main impacts of the construction sector since buildings would still generate unsustainable impacts in all the other stages of their life cycle, from material extraction to end of life. New energy-efficient buildings have higher embodied energy connected to their production and end-of-life stages, which may potentially hinder the benefits obtained during the use phase [4]. Moreover, when just the energy renovation is carried out without considering the structural vulnerabilities of a structure, losses may occur in the case of natural hazards, such as earthquakes, floods, etc., causing significant environmental, economic and social impacts [5].

In such a scenario, the need to reduce the impacts of the construction sector throughout its value chain and throughout a whole building life cycle becomes a priority to reach true carbon neutrality. According to the last European roadmaps and directives, this target would be met only by contextually adopting three strategies: (1) increasing the renovation rate of the existing building stock; (2) applying integrated retrofit interventions solving more building deficiencies, thereby fostering an enhanced concept of sustainability, one that encompasses eco-efficiency, safety and resilience [6]; and (3) adopting life cycle thinking (LCT) and circular economy approaches to substantially reduce all the possible impacts throughout a building's life cycle.

In the UNEP/SETAC definition, "Life Cycle Thinking means taking account of the environmental, social and economic impacts of a product over its entire life cycle (from raw material extraction through materials processing, manufacturing, distribution, use, repair and maintenance, and disposal or recycling) and value chain, from cradle to grave". A life cycle perspective thus "allows decision-makers to make choices that anticipate and optimally avoid any potential shifts of the environmental burden to other phases in the life cycle, to other impact categories, to other social groups, or in our globalized economy, to other regions of the world" [7].

When this perspective is applied to the construction sector, the life cycle of a building should be defined. According to EN15978 [8], 4 main stages should be considered: the product stage, the construction stage, the use stage, and the end-of-life stage, plus the potential life of the building components and material beyond the building's life cycle, in the case of reuse, recovery, and recycling (from cradle to cradle, according to the circular economy (Figure 1)).

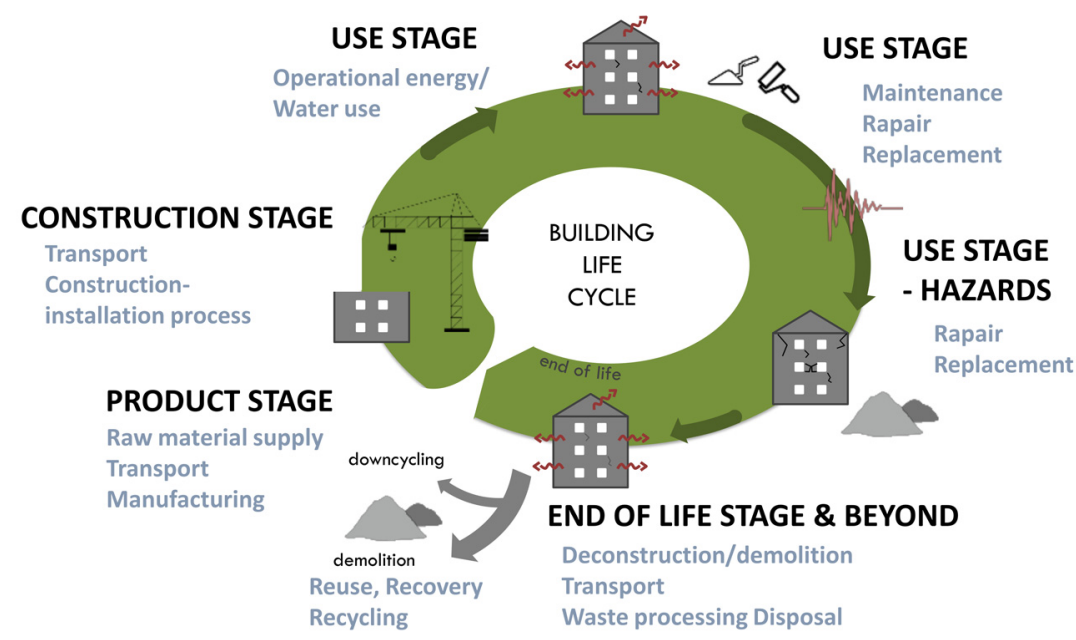

Figure 1. Building life cycle stages, according to EN15978 (2011) [8].

When life-cycle thinking is adopted as an ex ante design instrument, LCT-based principles may be defined for the design of a sustainable building or solution [9]. Some 
of these principles are defined in the Level(s) framework [10], in the guidelines for Green Public Procurement (GPP) [11], in the Green Building Rating System credits (e.g., LEED, DGNB, etc.), or in specific guidelines. Examples of design principles following a life cycle approach are: design for the eco-efficiency of materials, design for reducing construction site impacts, design for durability and maintenance, design for adaptability and renovation, design for deconstruction, reuse and recycling.

When considering a life cycle perspective for the design, all the possible scenarios experienced by the building throughout its life cycle should thus be taken into account; such scenarios vary as a function of the building typology and use, as well as of the building site. Depending on the building typology and use, scenarios connected to its maintenance or to its adaptation should be considered; while considering the building site, all the possible hazard scenarios should be addressed as a function of the actual hazard risk, both at a local and a regional scale (Figure 1). As a matter of fact, while sustainability is the leading-edge goal everywhere in the world, the actions aimed at achieving such a goal are necessarily site-dependent. In the case of buildings located in European countries, for example, the need to reduce/avoid environmental, economic, and social impacts connected to the possible occurrence of earthquakes or floods cannot be disregarded; in other countries, where droughts represent the major issues, water use and fire resistance may become critical. In these cases, new principles to reduce the possible losses due to hazardous events should be included in the preliminary stages of the design.

In this paper, the AdESA system, a new technique for the holistic and sustainable renovation of the existing building stock, is presented. The name AdESA is indeed the Italian acronym for "Adeguamento Energetico Sismico ed Architettonico", which means "Energy Seismic and Architectural Retrofit", and it is conceived in compliance with the life cycle thinking principles. AdESA is a dry retrofit technique consisting of a shell exoskeleton applied to the existing building, composed of 1,2, or 3 layers depending on the building needs and on the retrofit's main aims (structural retrofit, energy efficiency amelioration, architectural restyling), which can be easily adapted to different climatic and seismic zones. The shell exoskeleton is conceived as modular to adapt to different geometries and be flexible enough to adapt to possible future building needs. In order to overcome the barriers to the renovation and increase the actual renovation rate, the solution is conceived to be applied completely from the outside, reducing the time for the application and avoiding possible building downtime and the relocation of inhabitants, which are considered the major barriers to renovation $[12,13]$. The system is thus conceived to be applied for the holistic renovation of post-World War II buildings, often located in the urban outskirts and requiring architectural renovation, and it is not intended to be applied to either historical buildings or construction subject to preservation restrictions.

In this paper, the concept of the AdESA system is first described; then, the solution is applied to a real case study, a 50-year-old gymnasium located in Brescia, a city in a seismicprone area in northern Italy $(\mathrm{ag}=0.168)$ [14] and Climatic Zone E $(\mathrm{HDD}=2410)$ [15].

\section{AdESA System: An Anti-Seismic, Eco-Efficient Wooden Shell}

AdESA is a new system for the structural, energy, and architectural retrofit of the existing building stock of the urban outskirts [16]. The AdESA system entails the use of innovative technologies and virtual design systems (BIM), and it is based on the application of a layered shell to the existing building, encompassing: (1) a structural layer, consisting of an anti-seismic shell made of prefabricated cross-laminated timber (CLT) panels (or similar) and a fire protection layer, if necessary; (2) an energy layer, consisting of a thermal insulating coating; and (3) an architectural layer, encasing the previous layers with highly customizable finishes, ranging from simple skimming, to maintain the appearance of traditional plaster, up to coatings with high architectural and technological impact (Figure 2). 

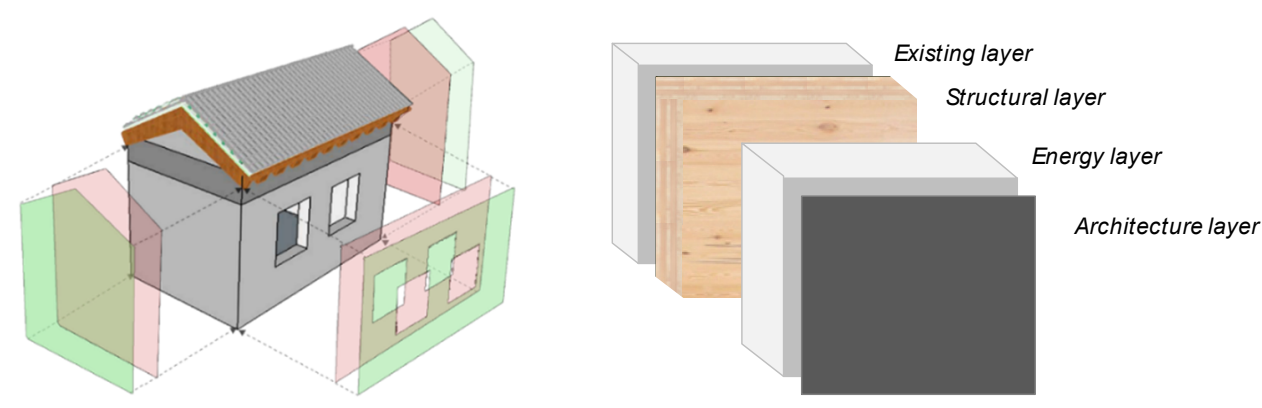

Figure 2. Holistic retrofit exoskeletons.

As for the structural and energy layers, they are applied only if needed. When the existing building is already provided with thermal insulation panels, the structural, architectural, and possible additional energy layers may be applied without removing the existing panels, except for those areas corresponding to the floor and the roof, where connections between the building and the shell are introduced. On the other hand, when a portion of the building does not need structural strengthening or requires minor interventions, the energy and architectural layers only may be implemented.

As for the architectural layout, depending on the urban constraints, the system allows for different levels of morphological transformation, determined by the choice of the shape of the shell and the offset from the existing building façades. The shell may be either in close proximity to the building, thereby creating a structural-energy coat, or placed at a distance to obtain volumetric expansion with the introduction of new living spaces.

The AdESA system was conceived to maximize the synergies of an integrated intervention, by reinvesting the tangible and immediate gain achieved with energy efficiency amelioration to partly compensate for the costs of the seismic improvement, thereby increasing the feasibility of the retrofit. In addition, the system was conceived as highly industrialized both in terms of the production process and for the installation of components, ensuring construction times, site management and costs comparable to those of energy and architectural interventions, but with additional benefits in terms of the safety of the building and of the inhabitants.

From an LCT point of view, the system is conceived to reduce environmental, economic, and social impacts throughout the whole building life cycle, and beyond, thus also implementing the concepts of the circular economy. In the production stage, the system adopts eco-efficient materials, either new and certified raw materials from renewable sources, with Environmental Product Declarations (EPD), or recycled/reused elements. Each component of the engineered shell is highly industrialized. Construction materials are optimized by providing multiple functions to the same element (e.g., reducing the thickness of the energy layer by exploiting the thermal properties of the structural panels, optimizing the traditional connection systems, etc.).

In the construction process stage, impacts are reduced through the adoption of dry technologies and the prefabrication of components. Components are pre-cut using computer-controlled cutting machines implementing BIM-based algorithms, transported to the construction site, and are easily moved by light cranes. Depending on the adopted technologies, structural, energy, and architectural layers may either be set up in sequence, at the construction site or previously assembled off-site and shipped as a unique modulus. Connections are also prefabricated in the factory and standardized to minimize installation operations, as well as to enable removal and reuse at the end of life; connection detailing is designed to enable managing the inevitable construction tolerances. Such precautions result in a fairly rapid on-site assemblage, as well as reduced costs and construction time.

In the use stage, the AdESA system is conceived not only to minimize the impacts connected to the operational energy through the thermal insulating layer but also to reduce the impacts connected to maintenance and repair, which are facilitated by prefabrication, standardization, and the dry assembly of each component. In addition, the system is 
conceived to minimize the impacts in case of earthquakes, not only by improving the seismic performance of the existing building to reduce/avoid damage to structural and nonstructural elements (low drift targets) but also by further engineering the connections to dissipate energy, amass the possible damage and act as structural fuses, easily replaceable after an earthquake.

Finally, in the end-of-life stage, the easy demountability of the system and the standardization of the elements allow the disassembling of the elements layer by layer and the reuse of the materials (for CLT panels, a reuse rate of about $85-90 \%$ may be considered, as the large panels can be easily tailored for further processing and reused; the standardized connection may be partially reused; as for the thermal layer, the possibility of reuse, recycle or disposal will depend on the durability of the adopted material). According to EN15978 [8], such features also enable the AdESA system to generate benefits beyond the system boundaries (i.e., the ones connected to reuse and recycling).

Similar retrofit systems, Energiesprong (https://energiesprong.org/ (accessed on 11 October 2021)) or Winterface [17], partly addressing the LCT approach, were developed within other European projects; however, such projects do not consider the structural deficiencies of the existing buildings, thus disregarding a critical phase of the building life cycle, i.e., the possible occurrence of earthquakes or other kinds of natural hazards. On the other hand, some research projects implementing CLT panels for the retrofit of existing buildings were developed [18-20], but without solving in a comprehensive manner all the correlated structural, energy, and technological issues and without addressing LCT principles. Finally, exoskeleton techniques for the holistic renovation of existing buildings considering different technologies have recently been proposed [21-25] but these are only at a conceptual level, with the sole exception of the first pioneering intervention developed by the authors of [26].

In the following section, a description of each layer composing the AdESA system is provided.

\subsection{Structural Layer}

From a structural point of view, exoskeletons may be designed by adopting two different structural schemes: the wall solution, which amasses the stiffness and resistance of the lateral force-resisting system (LFRS) into a number of discrete additional elements, and the shell solution, which exploits the extension of the building façades to reduce the thickness of the LFRS [27]. Both solutions require floor diaphragms to collect and transfer the seismic actions to structural exoskeletons. The need for floor diaphragms can be an issue if the existing floors were not engineered against seismic actions, especially in shell solutions, which require a higher capacity of the floors, provided that the spacing between the vertical element of the LFRS is generally larger than in the wall solution [28]. Accordingly, when designing new exoskeletons, particularly in the case of shell systems, the in-plane capacity of the existing floors and roof must be preliminarily assessed and possible reinforcements must be designed.

The structural conceptual design of the AdESA system entails a shell exoskeleton to be placed either in close proximity to or with an offset with respect to the building façade. The seismic-resistant layer of the AdESA system is composed of an outer wooden box structure made of CLT panels along the perimeter façades (arranged either horizontally, spanning between two adjacent floors, or vertically, spanning from ground to roof), a roof diaphragm, realized either by exploiting the existing roof or by adding new plywood panels mutually connected with nailed steel flanges [29], and the new foundation system of the wooden shell, consisting of RC perimetral curbs and micro-piles (Figure 3). The AdESA LFRS also encompasses floor diaphragms, either obtained by exploiting the existing floors or by introducing new intrados steel trusswork and steel-string courses to transfer the floor's inertia forces to the AdESA shell. 


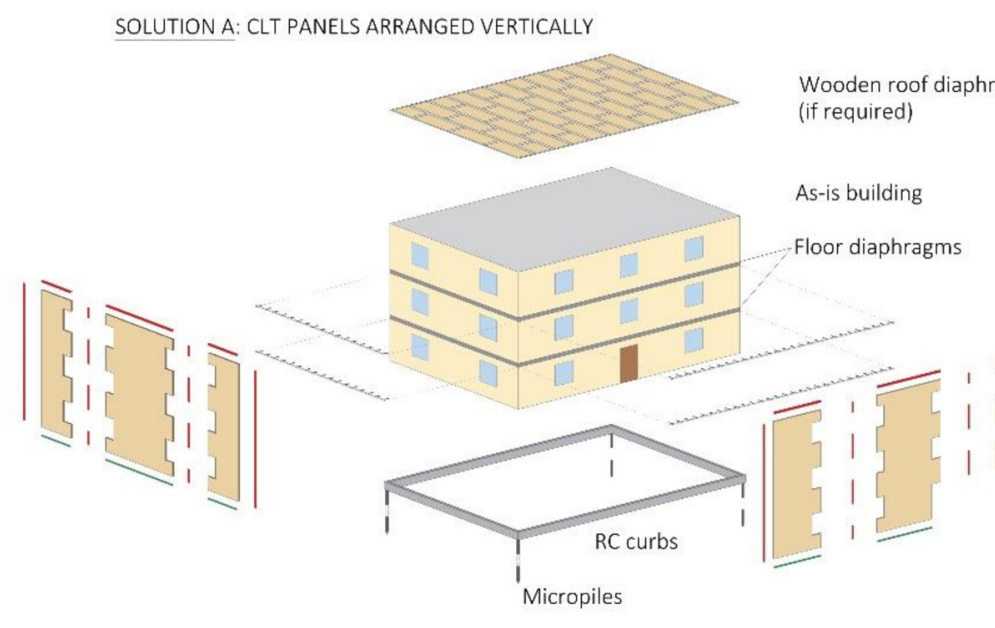

SOLUTION B: CLT PANELS ARRANGED HORIZONTALLY

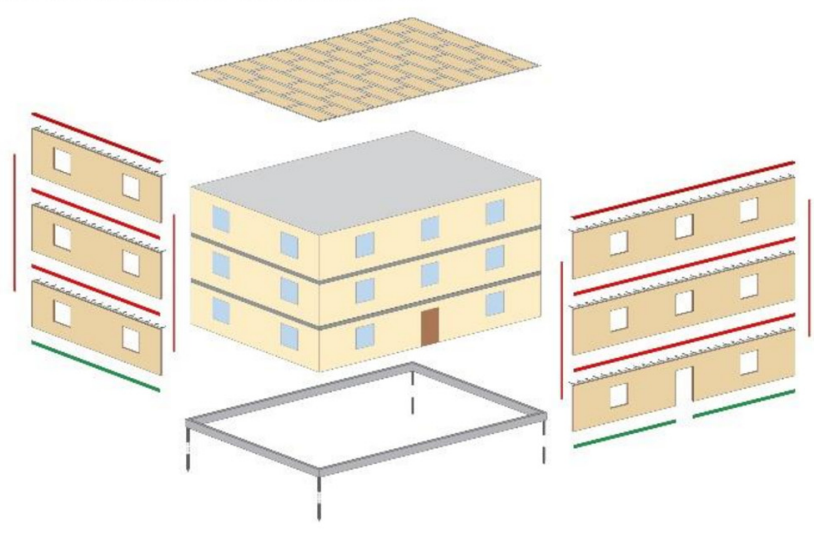

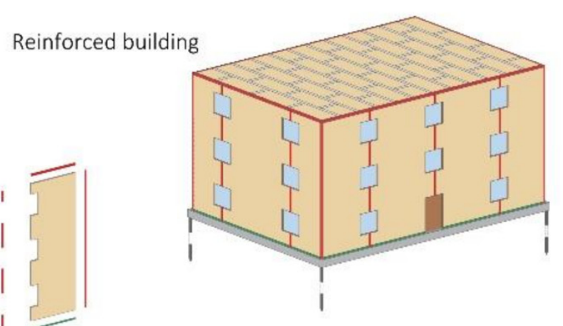

Prefabbricated CLT panels connected with: -roof and floor diaphragms -adjacent panels -new foundations

Figure 3. Structural layer of the AdESA system.

The structural shell requires three different types of connections: (1) connections among the panels; (2) connections between the shell exoskeleton and the existing building; (3) connections between the shell exoskeleton and the foundation system. The connections can be conceived to be either "over-resistant", i.e., designed to behave elastically throughout the seismic event, or "dissipative", to amass damage and to cap the seismic actions. Three examples of over-resistant and dissipative connections, specifically conceived for the AdESA system with horizontal panels, are reported in Figure 4. In the over-resistant solution, the lower panel is first stud-connected to the floor RC ring beam, and the upper panel is then connected to the lower panel by means of nailed steel strips; conversely, in the dissipative solution, an array of vertical steel plates is interposed at the connection level. Depending on the arrangement of the steel plates, dissipation can occur either in the shell exoskeleton, i.e., at the interface between the upper and lower panels, to cap the maximum actions in the shell, or between the shell and the existing building, i.e., at the interface between the shell exoskeleton and the string course fixed to the existing floor ring beam, to limit the maximum transferred shear floor action. The study of dissipative connections has led to the development of miniaturized connections, with weight and dimensions that can be handled manually by a single worker and composed of standardized elements that can be easily implemented according to specific needs. 

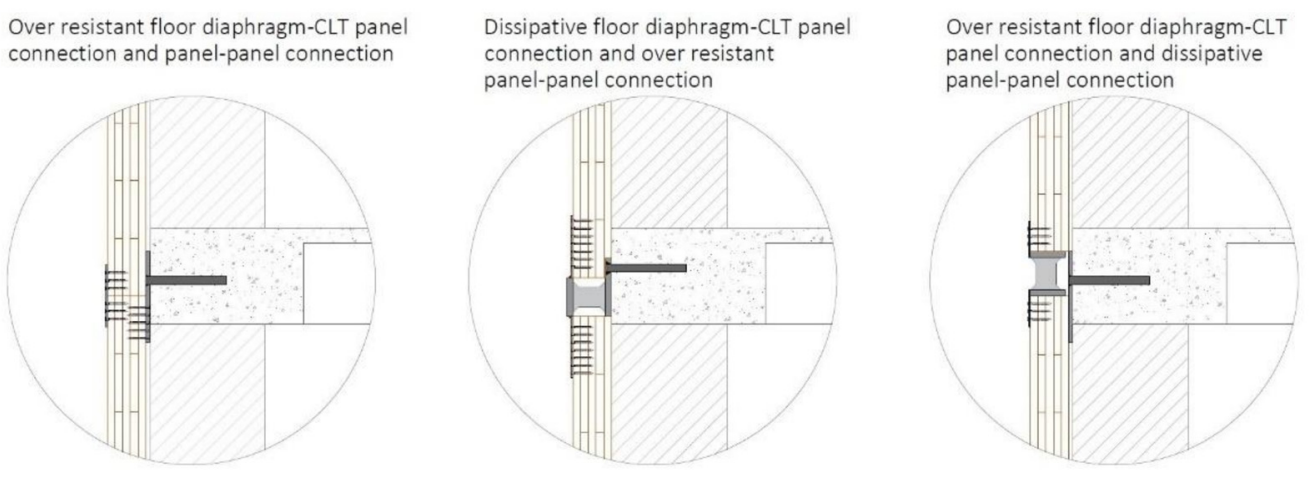

Figure 4. Possible technologies for over-resistant and dissipative connections.

In the case of CLT panels arranged vertically, it is possible to adopt additional types of connections, concentrating the dissipation at the interface between adjacent panels.

The panels are designed and cut to adapt to the geometry of the building façade, considering openings, balconies, lodges, overhangs, etc. In case of great irregularities to the façade, such as extended ribbon windows or lodges, a hybrid wooden-steel shell may also be adopted. As for the unevenness of the façades, such as those induced by the tapering of the existing wall thickness in elevation, this may not be considered as a problem, provided that the contact between the shell and the existing building is only required at the connection level. The thicknesses of the panels are defined on the basis of selected established performance objectives and two related structural design targets, namely: (1) the maximum inter-story drift at the life safety limit state, which may be lower than the limits imposed by the codes [14], depending on the desired level of protection of the structural and nonstructural elements of both the existing building and the AdESA shell exoskeleton; (2) the share of seismic action to be transferred to the shell with respect to the total seismic action on the building. Considering the geometric constraints and the design targets, the thickness of the panels and the number and type of connections may thus be proportioned. In the case of shear flow associated with common two-story buildings of traditional geometries, located in moderate seismic areas, the CLT panel thickness may range between 80 and $140 \mathrm{~mm}$.

According to LCT, in order to minimize the damage after an earthquake and thus minimize repair impacts/costs and building downtime, the LFRS may be designed by adopting more stringent performance objectives to limit the structural and nonstructural damage and to guarantee reparability. As an example, depending on the relevance of the building function, design professionals could decide to maintain all structural elements of the existing building and of the AdESA shell in the elastic range, ensuring the full operativity of the building both at the life safety limit state (LSLS) and at the collapse limit state (CLS) (in the case of strategic buildings, see [14]). Otherwise, one may decide to ensure an elastic behavior at the LSLS and dissipate energy at the CLS, by exploiting ductile structural connections and enforcing the onset of a ductile mechanism at collapse (in the case of ordinary buildings).

\subsection{Energy Layer}

As for the energy performances of the building, the AdESA system is conceived to minimize the primary energy consumption by improving the thermal insulation of the building envelope (coupling a thermal layer to the structural layer), reducing infiltration, and providing a better level of comfort for the users. Interestingly, in the design of the AdESA energy layer, the thermal properties of the wooden structural layer can be exploited in order to combine the insulation efficiency and the thermal inertia of the material. This way, the target energy consumption performances can be attained with a reduced thickness of the thermal insulation layer, minimizing the environmental impacts at the construction stage. 
A wide range of insulating materials may be adopted. In the following (Figure 5), a classification of the possible insulating material is proposed, which considers the technological and environmental characteristics of each thermal material, thus allowing for a more conscious selection of the energy solution. The materials are classified in terms of: material category (high-performance, foam, polystyrene, and fiber-based); cost ranges; insulation performance (equivalent thickness to obtain the same energy performance-transmittance $\mathrm{U}=0.2 \mathrm{~W} / \mathrm{m}^{2} \mathrm{~K}$ ); pros and cons; and "eco score". The "eco score" is an indication of the environmental impacts of each material throughout its life cycle (best performances are indicated by 1 , the worst by 4 ). The classification has been determined by considering the origin of the materials, their composition, and their possibility of being recycled/reused against their disposal, according to the work proposed by [30].

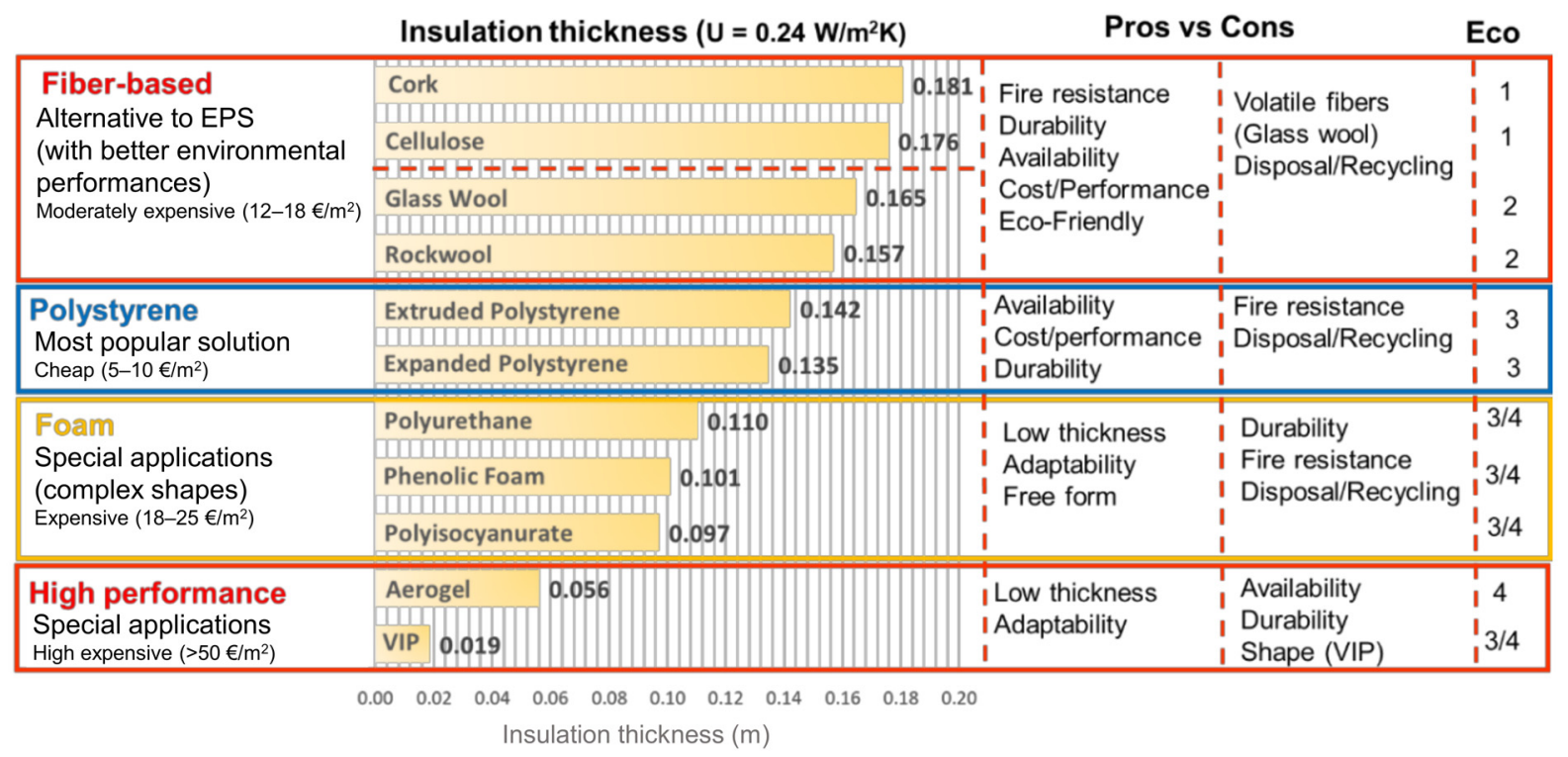

Figure 5. Properties of different thermal insulation materials to be applied for the energy layer of the AdESA system.

Considering such classification, in order to obtain the same energy performance, highperformance materials, such as vacuum insulation panels [31] or Aerogel blankets [32], require a lower thickness but have higher environmental impacts; on the other hand, more eco-efficient materials, such as natural fiber-based panels (cellulose, glass wool, rock wool panels), need a higher thickness, also having detrimental repercussions from the architectural point of view.

Parametric analyses were carried out to calculate the thermal transmittance of a building for different thicknesses of the thermal and of the CLT structural layer, both considering or neglecting the presence of the as-built construction and accounting for different insulating materials. Figure 6a shows the resulting wall thickness of different insulation materials, with the aim of achieving the selected thermal transmittance of $0.24 \mathrm{~W} / \mathrm{m}^{2} \mathrm{~K}$ to comply with the energy-saving regulations.

An example is reported in Figure $6 \mathrm{~b}$ for the combined thicknesses of a CLT structural layer (conductivity: $0.13 \mathrm{~W} / \mathrm{mK}$; capacity: $2.00 \mathrm{~kJ} / \mathrm{kgK}$; density: $600 \mathrm{~kg} / \mathrm{m}^{3}$ ) and of an expanded polystyrene (EPS) thermal layer (conductivity: $0.03 \mathrm{~W} / \mathrm{mK}$; capacity: $1.25 \mathrm{~kJ} / \mathrm{kgK}$; density: $25 \mathrm{~kg} / \mathrm{m}^{3}$ ), which is one of the most widespread insulating materials due to its good performance and low costs. For the configuration called "As-built + AdESA", a 12-centimeter inside concrete layer, a 6-centimeter outside concrete layer, and a 2-centimeter plaster layer were also considered. 


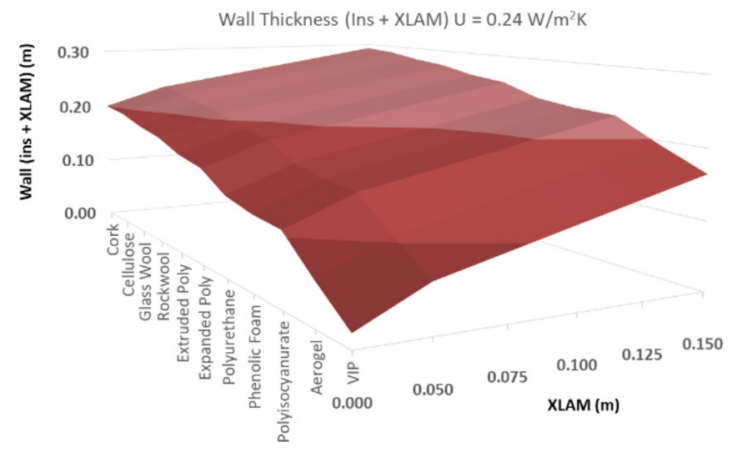

(a)

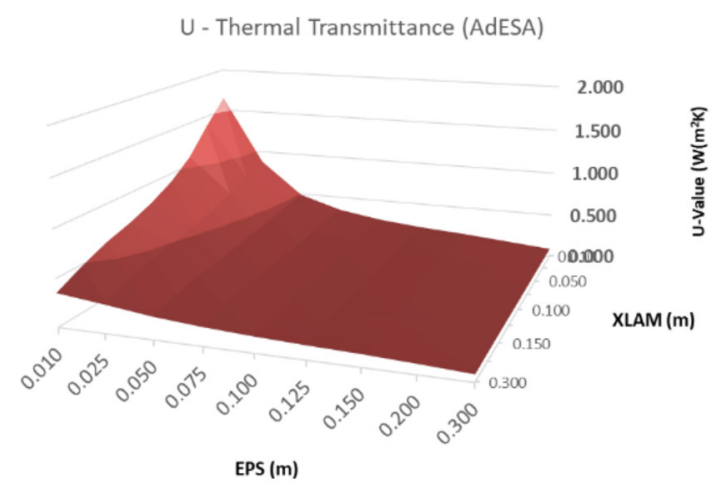

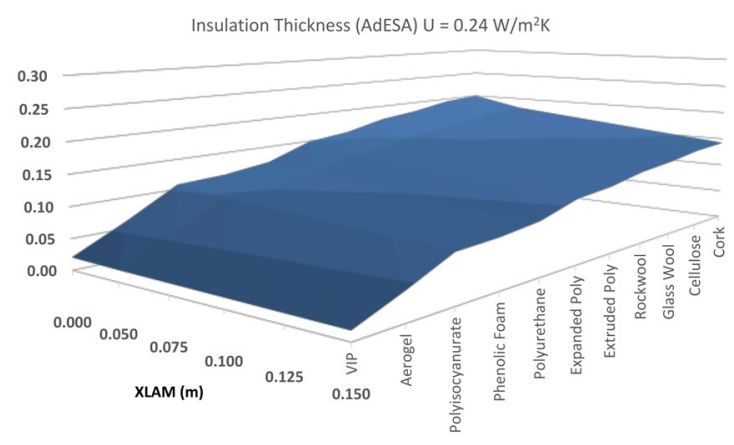

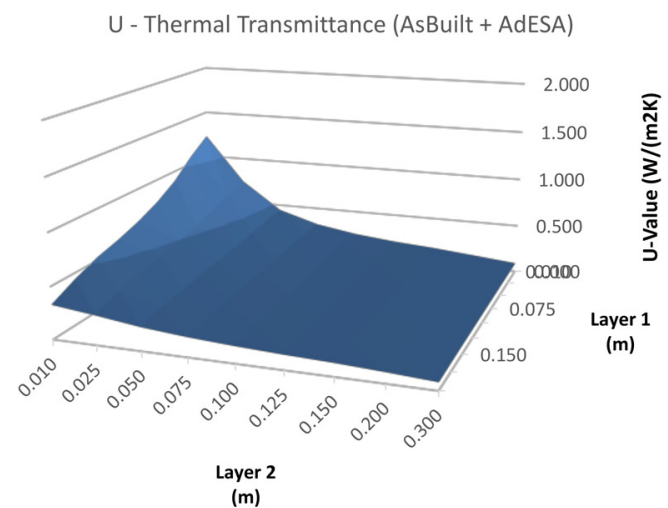

(m)

(b)

Figure 6. Parametric analyses considering: (a) the combined thicknesses of a CLT structural layer and different insulation material with a resulting thermal transmittance of $0.24 \mathrm{~W} / \mathrm{m}^{2} \mathrm{~K} ;(\mathbf{b})$ the combined thicknesses of a CLT structural layer and of an EPS thermal layer.

\subsection{Architectural Layer}

As for the architectural layer, the potential of the AdESA system can be expressed both in terms of customizable finishes and cladding and by the possibility of reconfiguring the building from a volumetric point of view by adding living spaces.

The possibility of multiple external finishes allows the customization of the building system. The choice is based on three main parameters: the type of cladding (membrane, slabs, panels, slats), the possible materials (steel, wood, cardboard, marble, brick, recycled materials), and the type of connection to the thermal layer (bolted, riveted, "clip-on", "concealed") and/or to the structural CLT layer. Approximately 60 products used in the building industry have therefore been cataloged to form a database that can be constantly implemented and is available for consultation [16].

The AdESA system was designed to provide for various levels of intervention, from a simple façade covering to a more complex volumetric expansion. The global or partial expansion of living spaces on the façade or roof, allowing the addition of balconies, terraces, solar greenhouses, or even new rooms, is made possible here by the additional structural layer, which in this case assumes a dual function: structural/seismic retrofit of the existing structure and load-bearing structure for the new spaces. The possibilities of intervention must be verified "case by case", depending on the needs of the decision-makers and the characteristics of the building and the urban fabric. An example of the architectural restyling of a typical post-World War II RC building adopting the AdESA system is shown in Figure 7 [33]. 


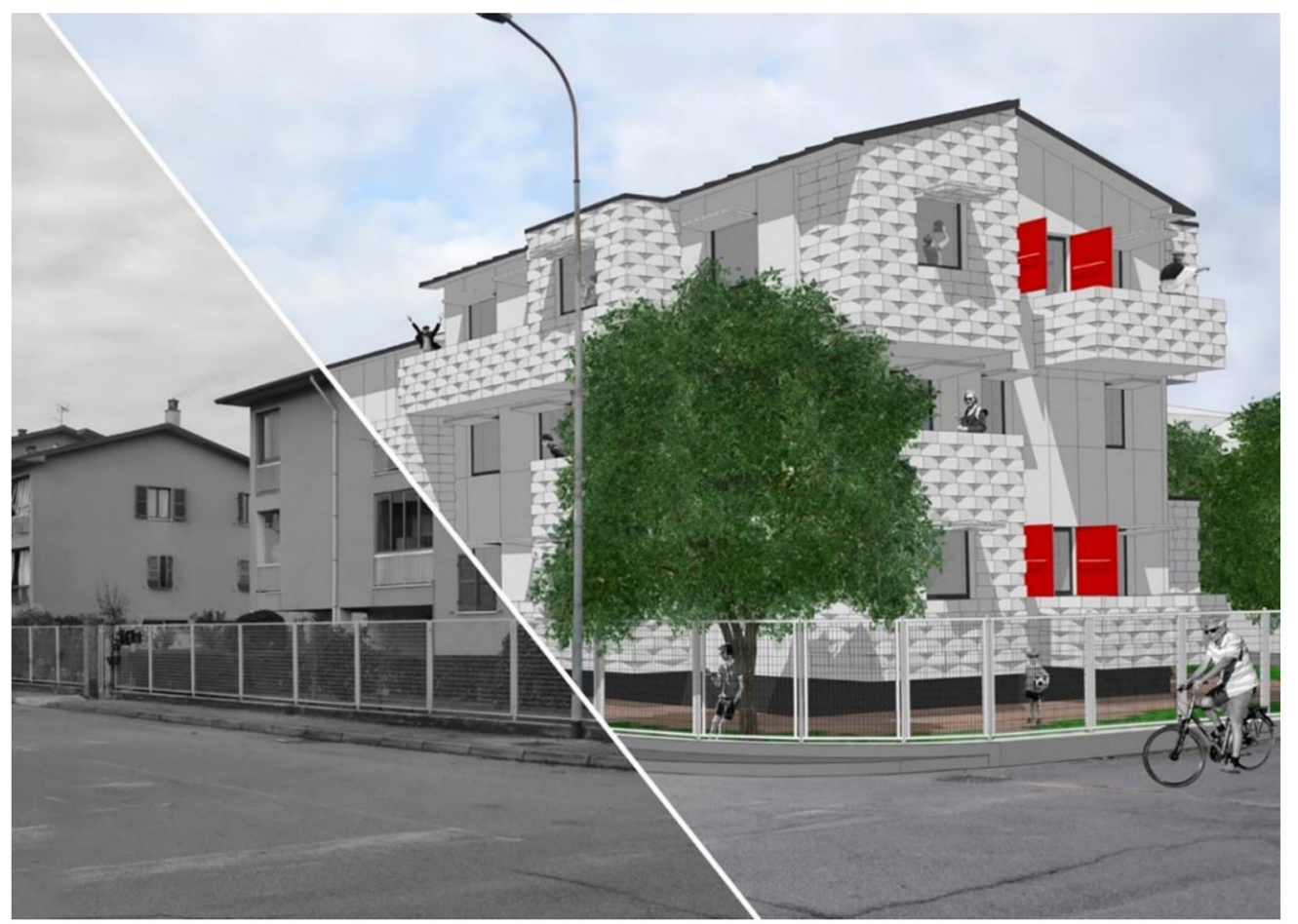

Figure 7. Example of an architectural layer of the AdESA system for a typical post-World War II RC building (before and after) Reprinted with permission from ref. [33]. Copyright 2019 Marco Abate.

\section{Application to a Real Case Study}

The AdESA system was first applied as a prototype to a case study, a gymnasium hall built in 1981, owned by the Municipality of Brescia, a city in northern Italy classified as being in a moderate-high seismic-prone zone $(\mathrm{ag}=0.168,[14])$ and Climatic Zone E (HDD = 2410, DPR 412/93). The gymnasium hall was first surveyed with laser-scanner techniques and validated with traditional geometric surveys, in order to obtain a georeferenced and measurable 3D model of the building envelope with high accuracy. From this first geometric model, additional structural and energy surveys were carried out, and a 3D BIM model was developed and later used as a reference for the architectural drawings and as the basis to develop the structural and energy models of the building in its as-is condition [16].

Structural, energy, and architectural/functional audits were then carried out to analyze the major vulnerabilities of the building and to define the performance objectives of the intervention. The design of the AdESA solution was carried out following a multidisciplinary approach, on the basis of joint energy, structural and architectural considerations. The project was then implemented in the BIM model, later used to extract construction documents, bills of quantities, drawings and specifications for the carpentry pieces, and assembly/construction instructions. The structural system was entirely prefabricated in the factory, shipped to the construction site, and assembled in situ. In this prototype case study, the three layers were assembled in sequence, upon completion of the innermost layer (structural layer, then energy and finishing layer). The ongoing re-engineering of the technique, particularly of the connections, will enable the preinstallation of the energy and finishing layers in the factory, to substantially reduce construction time; in situ operations will encompass the assemblage and covering of the interfaces between adjacent sandwich panels.

\subsection{Existing Building Performances in the As-Is Condition}

The case-study building is a reinforced concrete (RC) precast structure with a rectangular $25.34 \times 13.34 \mathrm{~m}^{2}$ plan and a height of $7.5 \mathrm{~m}$ (Figure 8 ). From the structural point of 
view, the building is conceived with a perimeter of $38 \times 38 \mathrm{~cm}^{2}$ columns with $6 \mathrm{~m}$ spacing, with corbels at mid-height for support of the intermediate edge beams and supporting the roof eave beams at the top. The intermediate edge beams support the precast cladding panels through mechanical connections via anchor channels, which inhibit the in-plane and out-of-plane displacement of the panels. The cladding panels are precast RC elements with a $2.4 \mathrm{~m}$ base, $8.1 \mathrm{~m}$ in height, and made of two RC layers $(6$ and $12 \mathrm{~cm}$, respectively) with a sandwiched insulating layer of 4-centimeter thickness. The roof is made of RC double tees with a total height of $47 \mathrm{~cm}$, 3.5-centimeter thickness of the upper flange, and a 12-meter span, without RC topping. These elements are supported by edge beams having inverted T-sections, supported on the columns, and connected to the cladding panels with the same devices as the intermediate edge beams. On the southern side of the building, an intermediate floor is located, hosting locker and storage rooms. The floor has a $5.7 \times 12.9 \mathrm{~m}^{2}$ plan and is divided into two main bays with a 6-meter span. Similar to the roof, this floor is made of RC double tees with $50 \mathrm{~cm}$ gross height and 3.5-centimeter thickness of the upper flange. These elements are also supported by inverted $\mathrm{T}$ edge beams, resting on the intermediate corbels of the columns. The floor is then complemented with a cast-in-place slab with a thickness of $7 \mathrm{~cm}$, to obtain a floor gross height of $50 \mathrm{~cm}$, and with integrative reinforcements in the beam-column joint. The foundations are made of $\mathrm{RC}$ pocket connected by an RC grade slab with a thickness of $20 \mathrm{~cm}$ and by a perimeter wall that distributes the loads transmitted by the columns as an inverted beam.
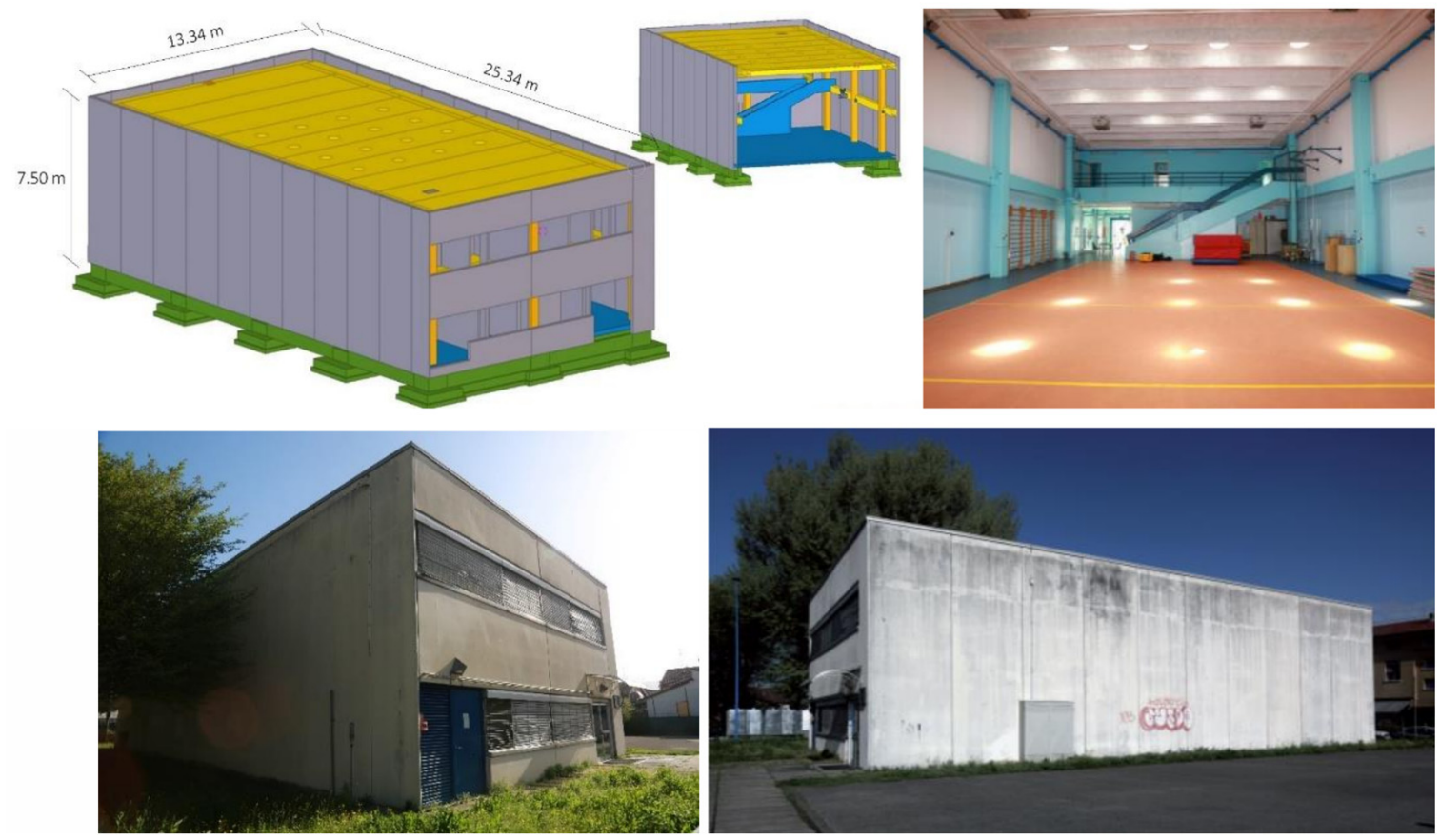

Figure 8. The 3D model obtained from the laser-scanner technique (top, left); the internal view of the southern portion of the structure with the intermediate floor (top, right); and the external view of the building (bottom).

From an esthetic and architectural point of view, the façades, consisting of RC precast cladding panels and ribbon windows on the short sides, show signs of decay related to the blackening of the panels, warping, and breakage of the blind slats, and graffiti and signs of vandalism. The relevant deflection of the flat roof, covered with gravel, accumulates rainwater in the central part. In addition, the courtyard has poorly maintained green spaces and an asphalted playground that is inadequately paved and poorly equipped for outdoor activities.

The 3D model obtained with the laser-scanner technique is reported in Figure 8, together with an interior view of the southern portion of the building. 
From a structural point of view, the building is an RC precast frame, with columns fixed at the base and beams hinge-connected to the columns. Being realized by double tees, the roof cannot be considered as a diaphragm but instead as a set of trusses. The intermediate floor is designed for sole gravity loads and is present in just a portion of the building; torsional effects may thus be expected in the case of earthquakes. RC cladding panels were not conceived as a lateral-load-resisting system; however, due to their high mass and stiffness and due to the low capacity of mechanical connections, they are expected to influence the structural response of the building against seismic loads.

In order to assess the structural and seismic vulnerabilities of the case-study building, two different 3D nonlinear models of the structure were assembled (Figure 9, herein referred to as "Mesh A" and "Mesh B"), and pushover analyses were carried out, adopting the software Midas Gen (2020) [34]. In Mesh A, only the main structural components (columns with isostatic beams) were modeled, while the secondary elements were considered only in terms of masses; in Mesh B, the precast cladding panels (modeled as beam elements) were also introduced, with their connections to the frame structure (modeled as general links with elasto-plastic behavior), considering their effective number, position, stiffness, and strength (more about the connections may be found in $[16,35]$ ). In both models, the roof precast double tees were modeled with truss elements linked to the edge beams; no roof diaphragm action can be attained in the as-is condition given the poor detailing and the lack of either double-tees mutual connections or extrados topping. On the other hand, the intermediate floor was modeled with plate elements to simulate its effective in-plane stiffness, enabled by the cast in situ topping. The possible interaction of the staircase, constrained to a perimeter column at the middle height, was also considered by introducing an absolute constraint to the horizontal translation at that point. As for the boundary conditions, columns were modeled as fixed to the ground, whereas cladding panels were modeled as pinned. Precast beams were modeled as single-bay elements, pinned to the columns.
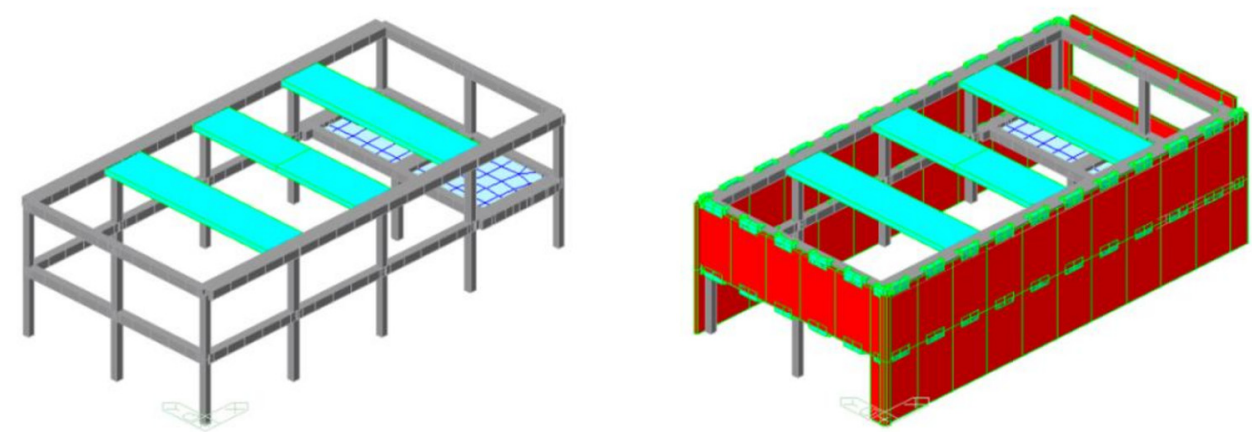

Figure 9. The 3D nonlinear models of the structure in the as-is condition: Mesh A, without cladding panels (left) and Mesh B, with cladding panels (right).

As expected, comparative analysis of the structural responses obtained from the two models allowed us to evaluate the difference in terms of stiffness, deformability, and vulnerability of the two structural layouts, highlighting the contribution of the cladding panels to the structural behavior against horizontal loads, which could not be neglected.

A comparison of the building capacity and the seismic demand $\left(d^{*} S L V\right)$ is reported in Figure 10, both considering (Mesh B) and disregarding (Mesh A) the precast cladding panels. In Mesh A, diffuse plasticization of the columns can be observed, until the ultimate bending deformation of the elements on the north façade is reached. These elements are indeed subject to greater deformations due to the torsional behavior induced by the in-plan and in-elevation irregularity of the building. The displacement capacity of the building is compatible with the demand at LSLS in Mesh A, in which only the main frame elements, characterized by high deformability capacity, were considered. However, this deformability is not compatible with that offered by the stiffer elements, such as cladding panels. In Mesh $\mathrm{B}$, the presence of the cladding panels with rigid connections leads to the premature 
failure of the connections on the north side, followed by the overturning of the cladding panels), with a significant loss of stiffness for the structure. After this point (dashed line), the capacity curve continues with the yielding of the columns and the attainment of the ultimate bending capacity of the elements on the first floor on the south side. However, the dashed portion of the curve has only a numerical meaning since the capacity of the building is considered as being limited to the point of the curve where the cladding panels connections fail. The displacement demand for LSLS is thus not satisfied, resulting in a safety index for the building in the as-is condition that is equal to 0.14 .
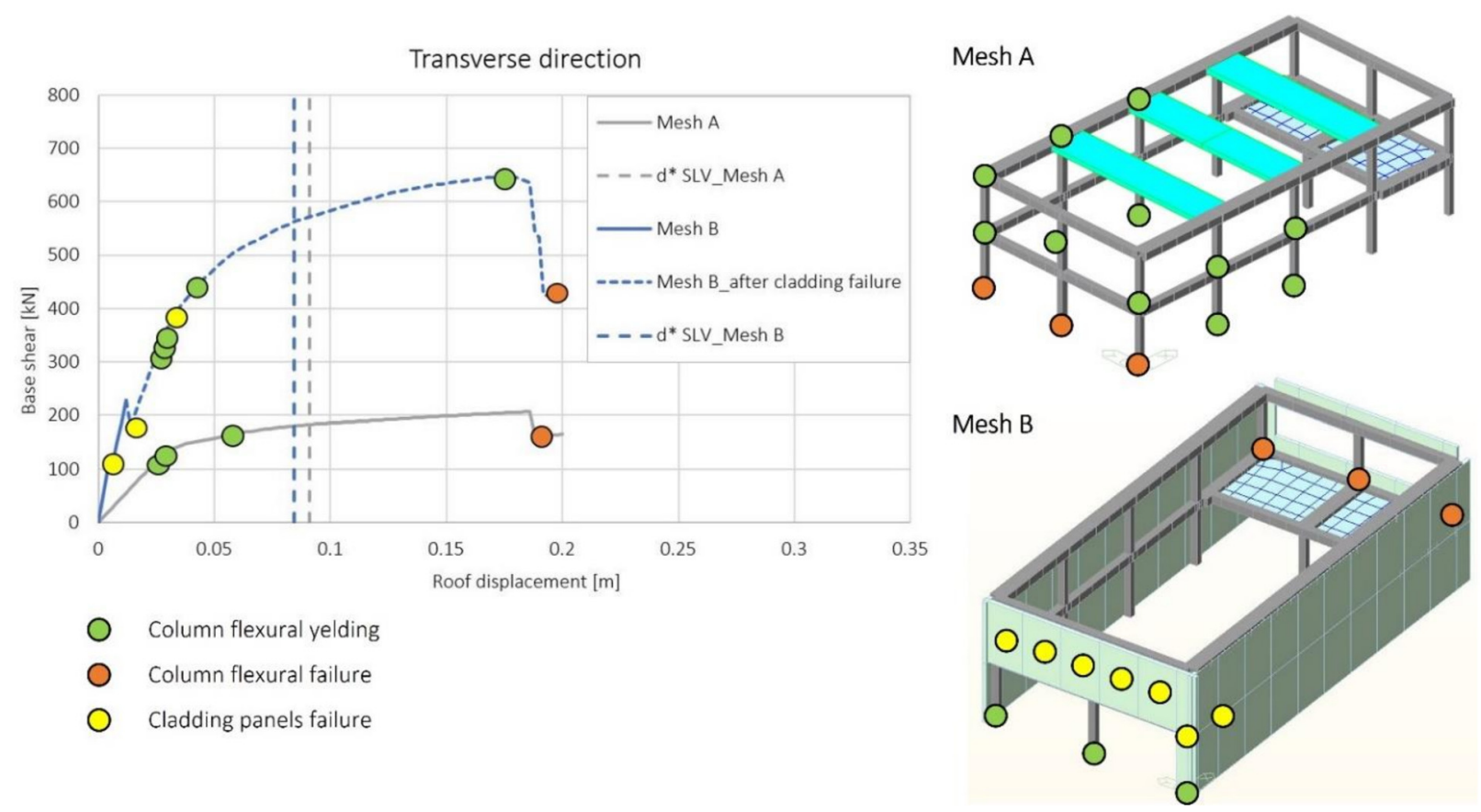

Figure 10. Structural performances of the building in the as-is condition.

From an energy point of view, the main deficiencies of the building were identified by analyzing its envelope, its plants, and the management of the building in terms of heating/cooling and air ventilation. As for the envelope, highly dispersing surfaces were identified both in the façade (RC sandwich panels with $4 \mathrm{~cm}$ of rock wool) and in the roof (5 cm of expanded cork).

In order to define the thermal demand for winter heating and summer cooling, accurate dynamic analyses were carried out, evaluating the behavior of the building for each hour of the year under certain conditions of use. The analyses were carried out by developing a numerical model using the Trnsys ${ }^{\circ}$ software [36], coupled with 3D geometrical models created with the Google SketchUp software, coupled with the plug-in Trnsys3D [37]. The geometrical model considers both the gymnasium and the surrounding neighborhood, so as to properly reproduce the shading and the interferences with buildings and vegetation (Figure 11b); the numerical model in Trnsys ${ }^{\circledR}$ completes the geometrical model with information about the envelope and the environmental variables, occupation/use and weather data from the Meteonorm database [38], which is characterized by accurate and reliable information. Figure 11a shows the simulated thermal load for winter heating (in red) and for summer cooling (in blue) for the building in the as-is configuration for each hour of a reference year, corresponding to a peak thermal load of $50 \mathrm{~kW}$ and an annual thermal load of about $63,000 \mathrm{kWh}$ for winter heating and a peak thermal load of $29 \mathrm{~kW}$ and an annual thermal load of about 21,000 kWh for summer cooling. 


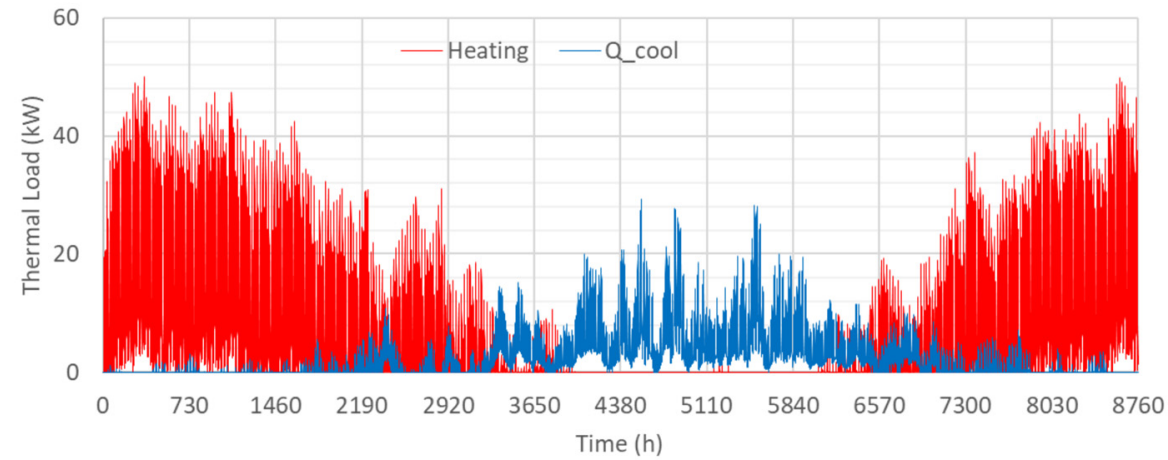

(a)

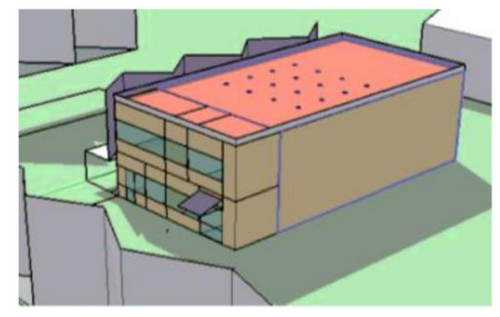

(b)

Figure 11. (a) Energy performances of the building in the as-is condition, (b) Trnsys ${ }^{\circledR}$ numerical model.

\subsection{Design of the Holistic Retrofit Intervention}

The AdESA system was adopted for the holistic retrofit of the building, tackling its multifaceted needs and vulnerabilities. All 3 layers (structural-energy-architectural) were implemented, albeit with partial re-engineering of the structural layer as required to adapt to the peculiarities of the existing building.

\subsubsection{Structural Intervention}

From a structural point of view, the AdESA system, conceived for traditional RC frame structures or masonry structures, was adapted to the specific features of the casestudy building, i.e., to account for the presence of full-height RC cladding panels, ribbon windows, an interior intermediate floor, etc. The resulting structural shell is composed of a seismic roof diaphragm on the top, additional hybrid wood/steel headwalls along the short sides of the building, where the ribbon windows are present, and concrete walls on the long side of the buildings, obtained by simply connecting the existing RC precast cladding panels. Despite partial re-engineering, the structural concept of AdESA as an outer shell connected from the outside to the existing structure was maintained but at the expense of the sustainability of the system, the hybrid system having higher environmental impacts than the original wooden system. According to the LCT principles, the damage induced by earthquakes to the existing building and to the AdESA system was limited by adopting quite demanding performance objectives in the design of the structural shell. The design was carried out by enforcing elastic behavior and full operativity of the building at the LSLS, and a ductile failure mechanism at CLS. The design targets were selected accordingly: a maximum inter-story drift ratio at LSLS equal to $0.5 \%$ and a maximum shear action in the shell façade, equal to $600 \mathrm{kN}$. These performances were achieved by introducing dissipative connections, which were conceived to be easily demountable and replaceable in case of activation, allowing an easy, fast, and cost-effective repair of the building after strong earthquakes.

The roof diaphragm was assembled above the existing roof (Figure 12) by addressing the technology and detailing presented in [29]. The diaphragm shear panel was made with 3-centimeter thick plywood panels, connected with each other by nailed steel flanges transferring the shear flow (nails $\phi 4 \times 2 / 5 \mathrm{~cm}$; flange: $\mathrm{s}=2 \mathrm{~mm}$ ), to the existing roof by means of vertical steel studs collecting seismic loads $(\phi 20 / 80 \mathrm{~cm})$ and deep anchors to prevent the diaphragm buckling, connected to the peripheral walls by means of steel studs transferring the shear flow to the seismic-resistant walls $(\phi 22 / 45 \mathrm{~cm})$ and thin ties preventing the wall out-of-plane overturning ( $3 \phi 10$ along the short sides, and $1 \phi 10 / 240 \mathrm{~cm}$ along the long sides, in red in Figure 12, left). L-shaped steel longitudinal profiles were introduced as perimeter chords in order to resist the bending moment (in blue in Figure 12, left). 

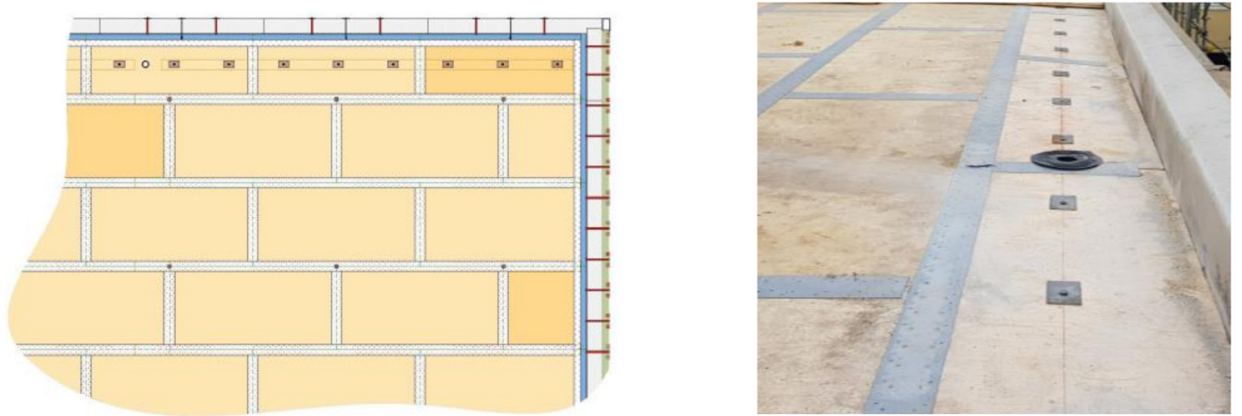

Figure 12. Roof diaphragm: concept (left) and realization before the introduction of the L-shaped steel elements (right).

Along the short side of the building, new seismic-resistant hybrid walls were placed in close proximity to the existing facades. These walls consist of CLT panels, $10 \mathrm{~cm}$ thick, alternating with welded steel frames (S355) made of box profiles with a rectangular section (horizontal tubular elements: $220 \times 120 \mathrm{~mm}, \mathrm{~s}=10 \mathrm{~mm}$; vertical tubular elements: $180 \times 120 \mathrm{~mm}, \mathrm{~s}=10 \mathrm{~mm}$ ). Steel frames were introduced due to the presence of the ribbon windows along the whole façade; a hybrid version of the AdESA structural layer, initially conceived as composed of CLT panels only, was thus obtained. The proportioning of the elements was preliminarily carried out for the façade stiffness to comply with the performance objectives by considering the shear stiffness of the wooden panels and the bending stiffness of the steel frames (Figure 13a).

The structural shell rests on a new foundation system consisting of RC curbs $(80 \times 30 \mathrm{~cm}$, $\mathrm{L}=1520 \mathrm{~cm}$ ) and micro-piles at the ends (one at each corner, $\phi 10 \mathrm{~cm}, \mathrm{~L}=15 \mathrm{~m}$ ). The reduced number and dimensions of the micro-piles provide evidence for the effectiveness of the shell structure in exploiting the extension of the façades to increase the lever arm and to reduce the magnitude of the vertical forces balancing the bending moment at the base level. The new foundation curb was stud-connected $(\phi 22 \mathrm{~mm} / 100 \mathrm{~cm})$ to the existing base RC slab and foundations to increase resistance against shear-sliding at the base.

As for the three typologies of structural connections, over-resistant stud connections $(\phi 22 \mathrm{~mm} / 50 \mathrm{~cm})$ were adopted to fix the walls to the existing floor and roof diaphragms (details 1 and 2 of Figure 13) and to connect the exoskeleton to the foundations (detail 4 of Figure 13). On the other hand, different elements of the shell exoskeleton, i.e., CLT panels and steel frames, were connected either with over-resistant connections (thin steel plates, with a thickness of $4 \mathrm{~mm}$, nailed to timber panels and welded to box-steel profiles) or with dissipative connections similar to the ones in Figure 4 (right), aimed at dissipating energy and limiting the loads induced by earthquakes (detail 3 of Figure 13).

These particular connections were conceived, tested, and placed along the short sides, in order to amass the most possible damage in case of high-intensity earthquakes and enable activating a ductile mechanism at CLS. These connections are composed of an array of steel plates ( $\mathrm{s}=8 \mathrm{~mm}, \mathrm{~h}=100 \mathrm{~mm}, \mathrm{~b}=100 \mathrm{~mm}, 300 \mathrm{~mm}$ spacing), subjected to out-of-plane bending, and are conceived as a way to cap the seismic action $\left(\mathrm{F}_{\mathrm{y}, \mathrm{cap}}=12 \mathrm{KN}\right)$, thereby maintaining the panels and steel frames in the elastic field (Figure 14). The dissipative device was nailed to the CLT panel $(\phi 4 / 50 \mathrm{~mm})$ and welded to the steel frame to transfer the shear flow. Figure 14 shows the setup of the cyclic tests carried out at the University of Bergamo and the obtained hysteretic loop of the connection, as well as the dissipative connections after their assemblage on-site. Finally, mechanical anchors were adopted to constrain the CLT panels and the steel frames against out-of-plane loading (Figure 13b). 

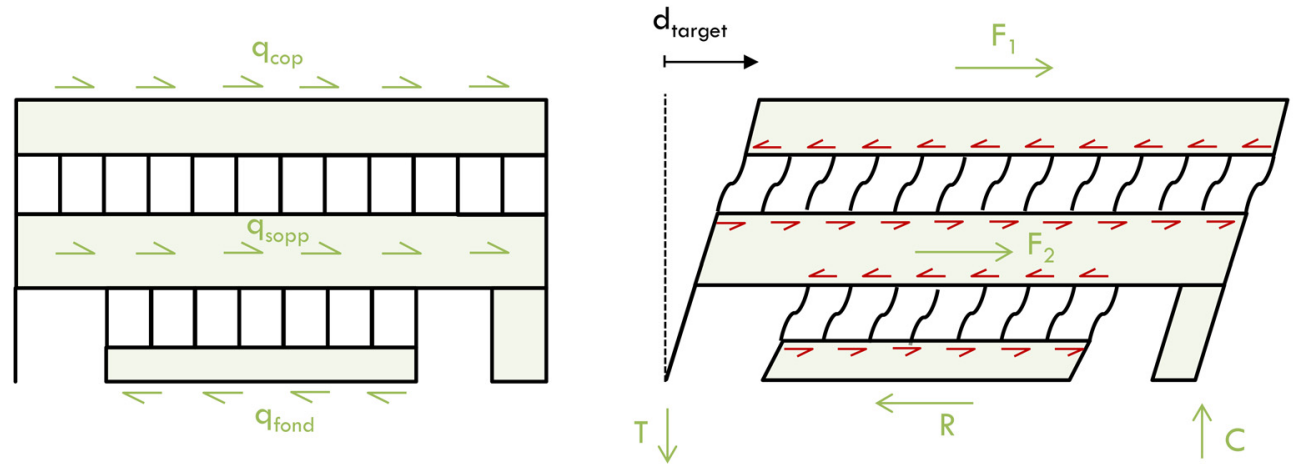

(a)
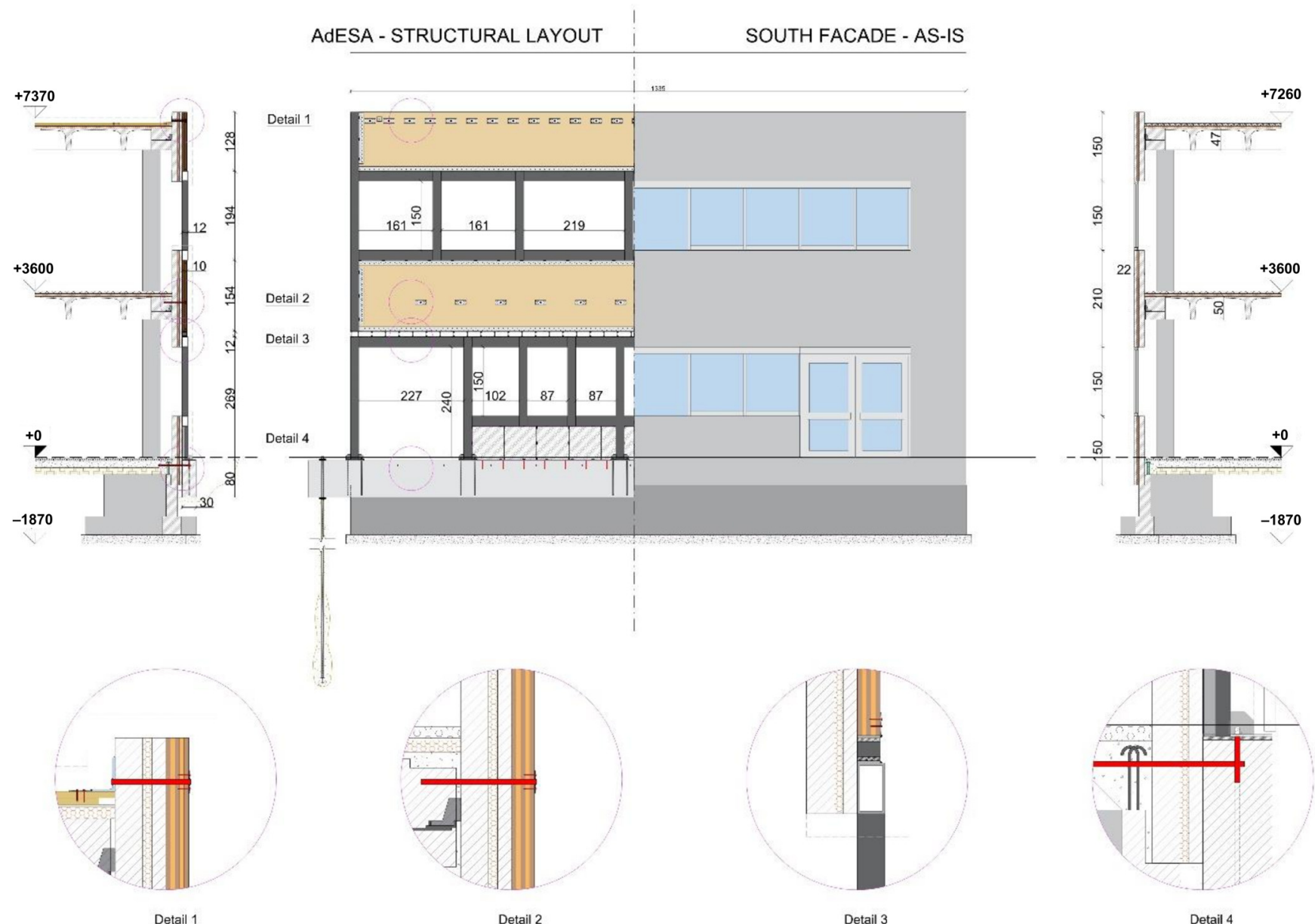

(b)

Figure 13. Structural intervention along the short façades of the building: (a) structural scheme; (b) section, front view and details (all measures in centimeters).

In Figure 13b, the elevation of the southern façade is reported before (left) and after (right) the structural intervention. In Figure 13b (left), it is possible to distinguish the CLT panels (in orange), the steel frames (in dark grey), the connection to the roof and to the intermediate diaphragms (rectangular plates), the dissipative connections located between the steel frame at the ground floor and the intermediate wooden panels (array of vertical steel plates), and the new foundation system (curb—in a diagonal square pattern-and micropile at the building corner). Pictures of the construction stage of the prefabricated CLT panels are shown in Figure 15. 

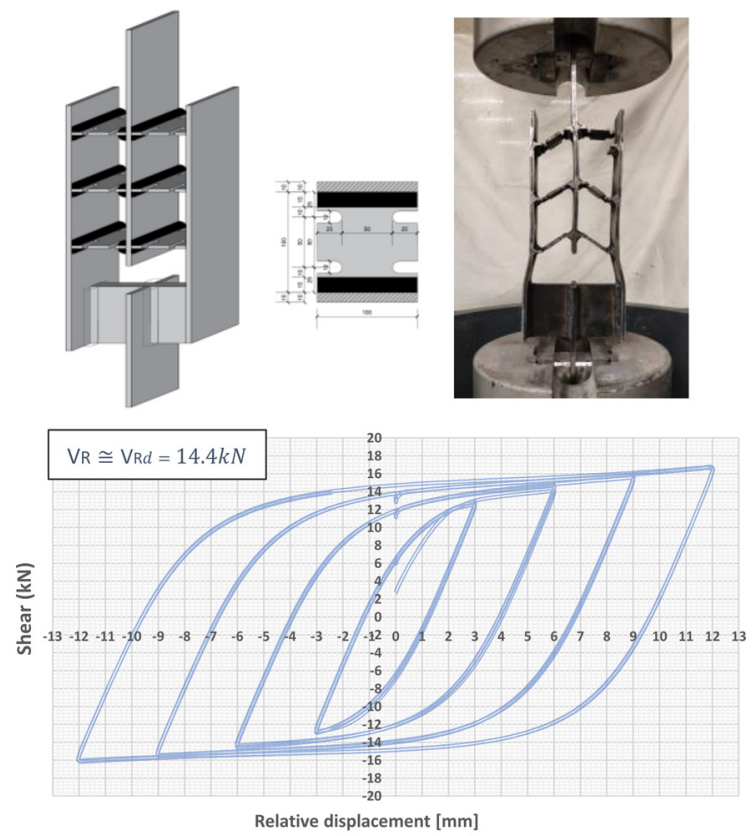

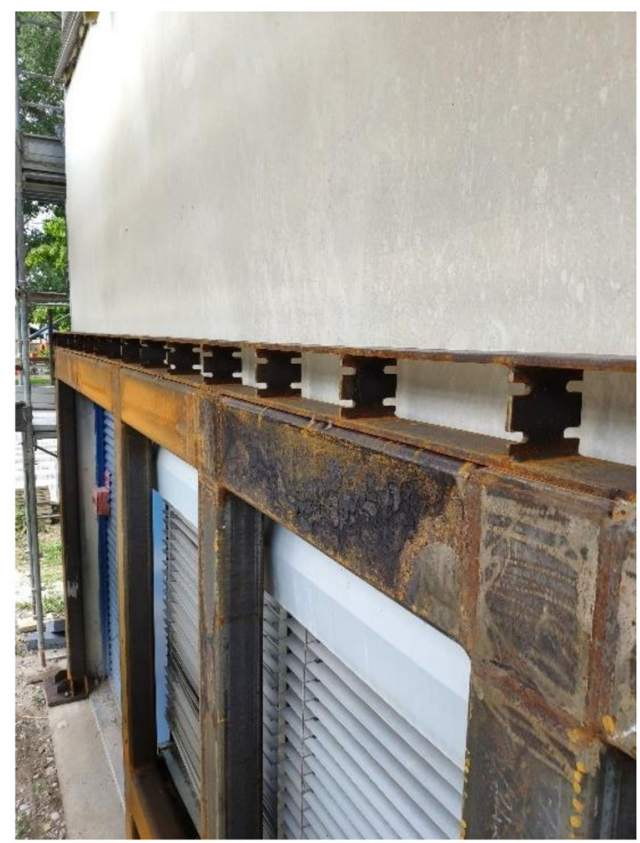

Figure 14. Details of the connections conceived as sacrificial replaceable elements (test setup and results, and connections in place).
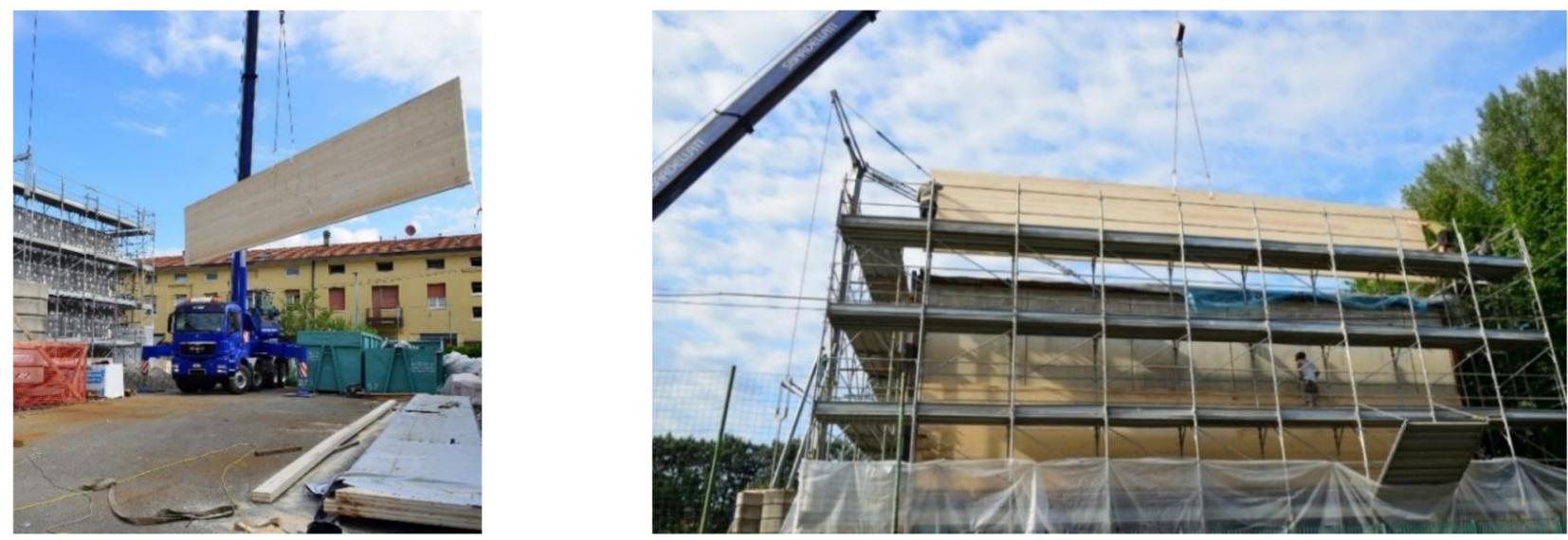

Figure 15. Details of the prefabricated structural intervention under construction.

Along the long side of the building, the seismic-resistant façades were obtained from exploiting and re-engineering the existing elements, thus avoiding the introduction of the CLT structural layer. To increase the in-plane stiffness and strength of the LFRS, mechanical connections made of $10 \mathrm{~mm}$ steel plates and $\phi 20$ studs, 8 on each vertical element, were introduced between adjacent cladding panels to enforce the coupling of the panels. The elements of the connection system were designed according to the simplified structural scheme of Figure 16 (top) and were then verified in the global model of the retrofitted building. The structural façade was connected with $\phi 22 / 50 \mathrm{~cm}$ studs to the roof diaphragm and to the existing foundation, to transfer shear flow. Mechanical anchors were also adopted to fix the structural façade to the roof diaphragm, to inhibit out-ofplane overturning in the case of seismic action acting in the transverse direction. The stiffness and the capacity of the connection between the panels were defined as a function of the geometry of the precast panels and to guarantee the respect of the design targets (Figure 16a). 

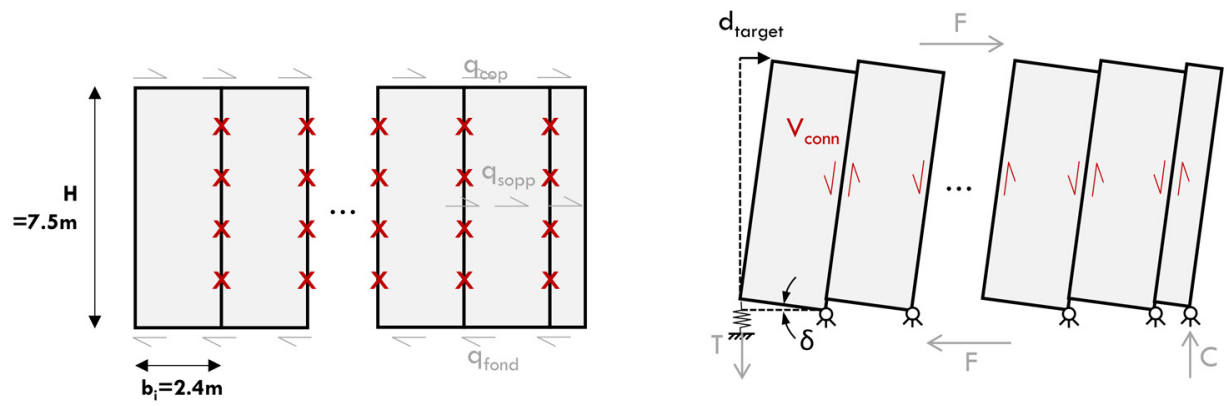

(a)

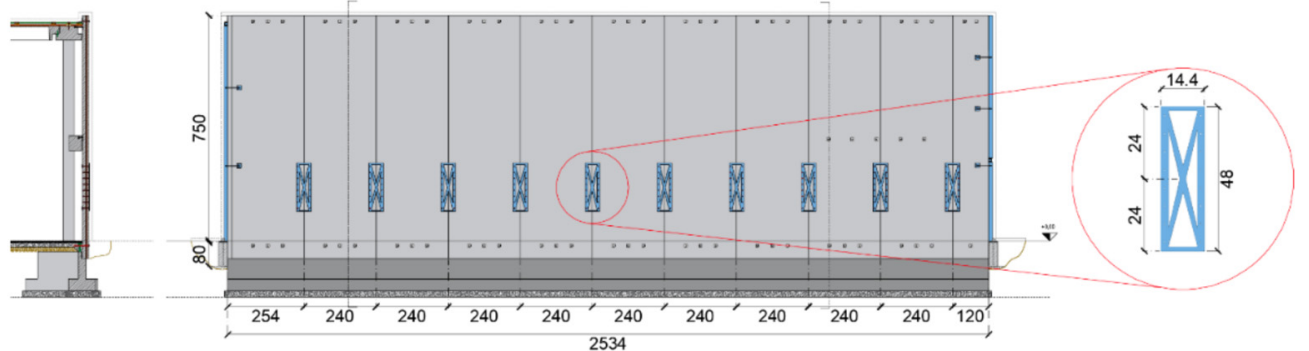

(b)

Figure 16. Structural intervention along the long sides of the building: (a) structural scheme; (b) section, front view and detail (all measures in centimeters).

In Figure 16b, the elevation of the western façade after the structural intervention is reported. It is possible to distinguish the existing precast panels (in light grey), the connections between the panels (in light blue and in Figure 17a,b), the connection to the roof, to the foundations, and to the intermediate diaphragms (square plates) and the existing foundation system (in dark grey). In Figure 17c the connections avoiding the out of plane of the additional CLT panels are also shown.

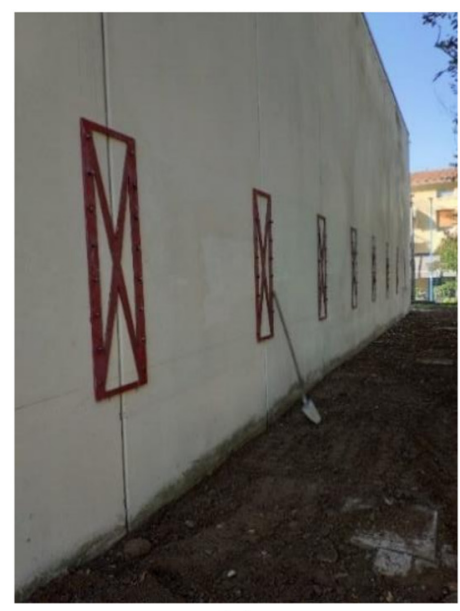

(a)

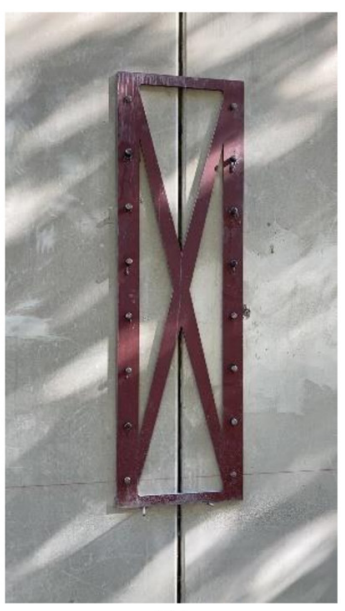

(b)

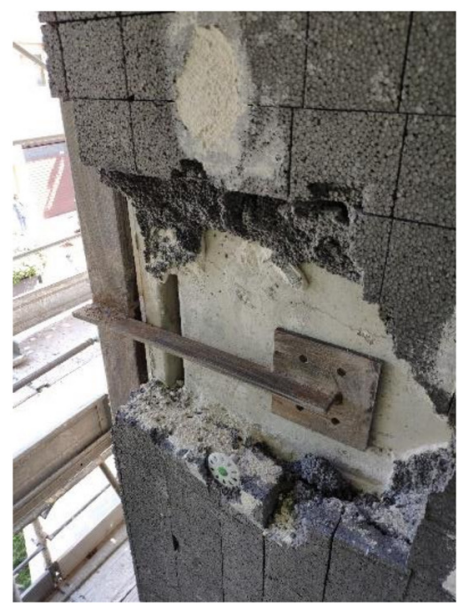

(c)

Figure 17. Mechanical anchors between the panels (a,b) and adopted to constrain the CLT panels (c).

The structural intervention was conceived and designed through the simplified static schemes described above and its effectiveness was assessed through non-linear dynamic analysis (time history).

The structural intervention was simulated in Mesh C (Figure 18 left), implemented based on Mesh B. Along the longitudinal facades, general links were introduced to simulate the new shear connections between the adjacent cladding panels. Connections were modeled as spring-general links, defined in terms of strength and stiffness by adopting 
a bilinear elasto-plastic hysteretic model. The characteristics of each connection were calibrated as a function of the properties of the stud and of the connected layers. Along the short facades, the AdESA structural layer was modeled with plane stress elements for the CLT panels, beam elements for steel frames, and general elasto-plastic links for all the connections with the existing building and between the new structural components. Each general link's stiffness and strength were calibrated on the basis of theoretical formulations adopted in the design phase [39] and the results were obtained through experimental tests conducted at the laboratory of the University of Bergamo (Figure 12). At the roof level, a rigid diaphragm was introduced to account for the stiffening contribution of the new seismic wooden diaphragm. All the properties of the FEM model of the retrofitted building (Mesh C) are reported in Table 1.
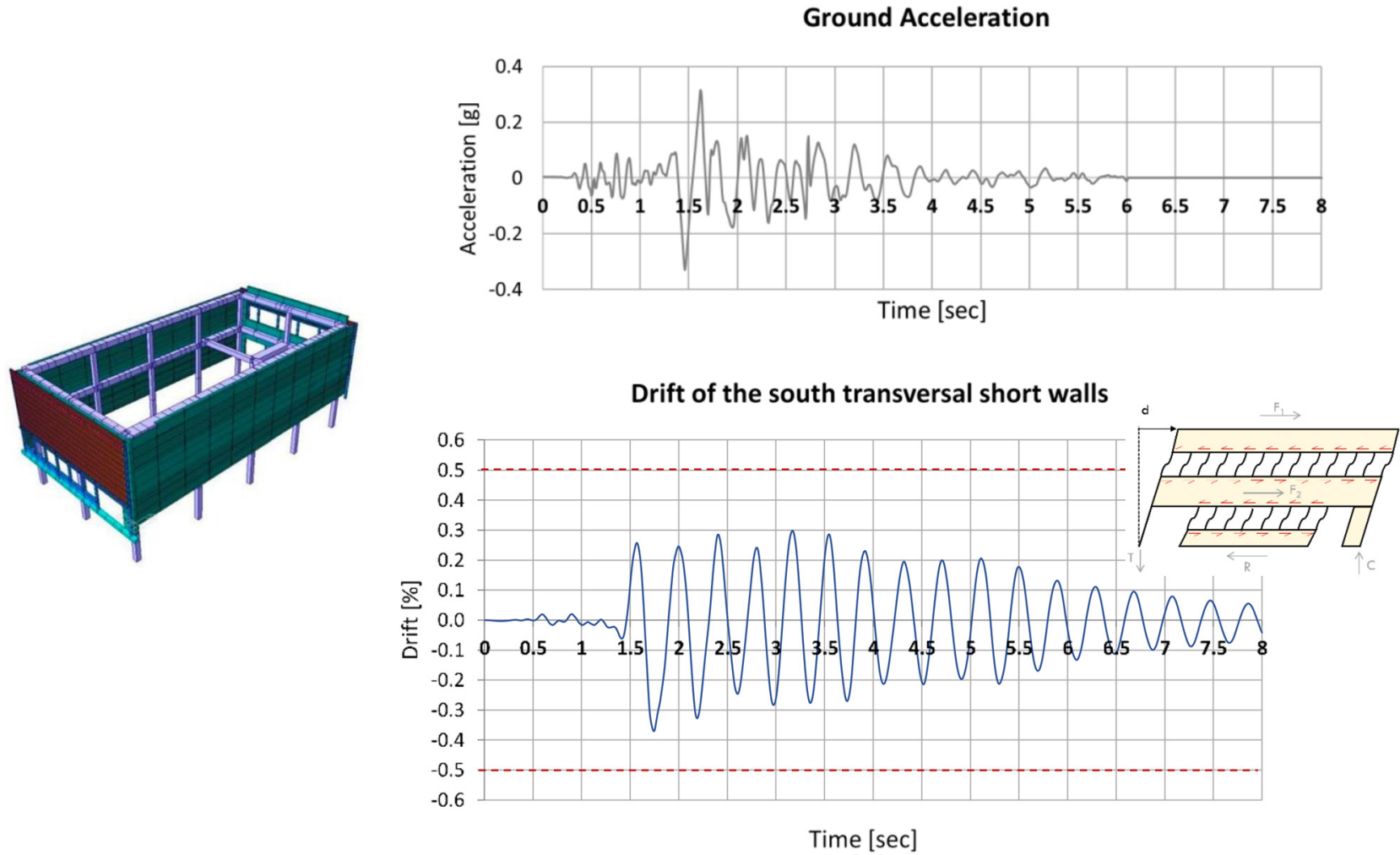

Figure 18. FEM model of the retrofitted building (Mesh C) (left); examples of ground acceleration (right bottom) and drift of the south transversal wall (right top).

Table 1. Major features of the model for the retrofitted building (Mesh C).

\begin{tabular}{|c|c|c|c|}
\hline $\begin{array}{l}\text { North and South } \\
\text { Facades Retrofit }\end{array}$ & Element Typology & $\begin{array}{l}\text { Finite Element } \\
\text { Modeling }\end{array}$ & Description \\
\hline Steel Frames & $\begin{array}{l}\text { Hollow square } \\
\text { profiles and plates } \\
\text { in mild steel S355 }\end{array}$ & $\begin{array}{l}\text { Elastic beam } \\
\text { elements }\end{array}$ & $\begin{array}{c}\text { The steel frames located around the ribbon windows } \\
\text { are modeled as 1-dimension elastic beam elements } \\
\text { pinned to the RC curbs }\end{array}$ \\
\hline CLT panels & $\begin{array}{l}100 \mathrm{~mm} \\
\text { X-LAM }\end{array}$ & $\begin{array}{l}\text { Plane stress } \\
\text { elements }\end{array}$ & $\begin{array}{l}\text { These elements are modeled as 2D plane stress } \\
\text { elements fixed to adjacent steel elements }\end{array}$ \\
\hline $\begin{array}{l}\text { "Over-resistant" } \\
\text { connections }\end{array}$ & Steel studs in S355 & $\begin{array}{l}\text { Spring general } \\
\text { links }\end{array}$ & $\begin{array}{l}\text { The "over-resistant" connections used to link the } \\
\text { shell exoskeleton to the existing building, to the roof } \\
\text { and to the foundation system are modeled as } \\
\text { elasto-plastic spring general links, described in } \\
\text { terms of strength and stiffness }\end{array}$ \\
\hline
\end{tabular}


Table 1. Cont.

\begin{tabular}{|c|c|c|c|}
\hline $\begin{array}{l}\text { "Dissipative" } \\
\text { connections }\end{array}$ & $\begin{array}{l}\text { Steel plates in mild } \\
\text { steel S275 }\end{array}$ & $\begin{array}{l}\text { Elasto-plastic beam } \\
\text { elements }\end{array}$ & $\begin{array}{l}\text { The "dissipative" connections between elements of } \\
\text { the exoskeleton are modeled as an array of } \\
\text { elasto-plastic beam elements able to dissipate the } \\
\text { seismic energy introduced by yielding, limiting the } \\
\text { maximum shear forces }\end{array}$ \\
\hline $\begin{array}{l}\text { East and West Facades } \\
\text { Retrofit }\end{array}$ & Element Typology & $\begin{array}{l}\text { Finite Element } \\
\text { Modeling }\end{array}$ & Description \\
\hline \multirow{3}{*}{$\begin{array}{l}\text { Mechanical connections } \\
\text { between RC cladding panels } \\
\text { "Dissipative" studs between } \\
\text { steel plates and RC cladding } \\
\text { panels }\end{array}$} & $\begin{array}{l}10 \mathrm{~mm} \text { plates in } \\
\text { mild steel S355 }\end{array}$ & $\begin{array}{l}\text { Spring general } \\
\text { links }\end{array}$ & $\begin{array}{c}\text { These mechanical connections are modeled as elastic } \\
\text { springs, described only in terms of stiffness }\end{array}$ \\
\hline & Steel studs in S355 & $\begin{array}{l}\text { Spring general } \\
\text { links }\end{array}$ & $\begin{array}{c}\text { The dissipative studs used to connect the steel plates } \\
\text { to the RC cladding panels are modeled using } \\
\text { elasto-plastic spring general links }\end{array}$ \\
\hline & Steel studs in S355 & $\begin{array}{l}\text { Spring general } \\
\text { links }\end{array}$ & $\begin{array}{l}\text { The "over-resistant" connections used to link the RC } \\
\text { cladding panels to the new roof diaphragm and to } \\
\text { the existing base RC slab are modeled as } \\
\text { elasto-plastic spring general links, described in } \\
\text { terms of strength and stiffness }\end{array}$ \\
\hline $\begin{array}{l}\text { Roof } \\
\text { Retrofit }\end{array}$ & Element Typology & $\begin{array}{l}\text { Finite Element } \\
\text { Modeling }\end{array}$ & Description \\
\hline $\begin{array}{l}\text { Wooden shear panels and } \\
\text { L-shaped steel } \\
\text { longitudinal profiles }\end{array}$ & $\begin{array}{l}\quad 30 \mathrm{~mm} \text { thick } \\
\text { structural plywood } \\
\text { panels and L-shape } \\
\text { steel profile in mild } \\
\quad \text { steel S355 }\end{array}$ & Rigid diaphragm & $\begin{array}{c}\text { The new roof diaphragm is modeled as a } \\
\text { rigid diaphragm }\end{array}$ \\
\hline $\begin{array}{l}\text { “Over-resistant" } \\
\text { connections }\end{array}$ & Steel studs in S355 & $\begin{array}{l}\text { Spring general } \\
\quad \text { links }\end{array}$ & $\begin{array}{l}\text { The "over-resistant" connections used to link the } \\
\text { new roof diaphragm to the new exoskeleton } \\
\text { (North/south) and to the RC cladding panels } \\
\text { (East/West) are modeled as elasto-plastic spring } \\
\text { general links, described in terms of strength } \\
\text { and stiffness }\end{array}$ \\
\hline
\end{tabular}

The nonlinear time-history analyses were carried out by considering seven Italian natural accelerograms selected as compliant with the site's elastic spectrum, adopting the Rexel Software [40]. The earthquakes with the maximum peak ground velocity were selected. In the design, the life safety limit state (LSLS, [14]) was considered. Numerical results are summarized in Table 2 in terms of the average of the maximum response of each accelerogram, and an example of drift time history is represented in Figure 18. For all the selected accelerograms, thanks to the activation of the dissipative connections on the short sides of the exoskeleton, the maximum drift was always lower than the considered drift target (equal to $0.5 \%$ ), which allowed us to maintain the additional steel frame in the elastic range and to limit the damage in the elements of the existing RC frame. In addition, the maximum shear capacity of the existing connections was never reached.

Table 2. Main results of the time history analyses on the retrofitted building (adapted from AdESA 2019).

\begin{tabular}{|c|c|c|}
\hline & $\begin{array}{l}\text { Max Drift } \\
\quad[\%]\end{array}$ & Plastic Hinge Activation \\
\hline $\begin{array}{l}\text { Transversal short walls } \\
\text { (North and South) }\end{array}$ & 0.36 & $\begin{array}{c}\text { Plasticization of dissipative connections, elastic behavior of steel frames and } \\
\text { CLT panels }\end{array}$ \\
\hline $\begin{array}{l}\text { Longitudinal long walls } \\
\text { (East and West) }\end{array}$ & 0.12 & $\begin{array}{l}\text { Plasticization of dissipative connections and the activation of rocking at the base of } \\
\text { panels with limited displacement }\end{array}$ \\
\hline Existing Structure & 0.48 & Limited plasticization in pillars \\
\hline
\end{tabular}


According to the LCT principles, the AdESA system was conceived to minimize the impacts both during and after the seismic event. Amassing the whole seismic damage in the dissipative connections allowed the construction to preserve all the other elements of the exoskeleton and of the existing building. In addition, the connections were designed to be easily demountable and replaceable, allowing easy, low-cost, and rapid repair of the building, avoiding downtime of the building's functions.

\subsubsection{Improvement of Energy Efficiency}

The objective of the energy-efficiency amelioration measures was to reduce the building's consumption and improve thermal comfort. This was obtained from insulation systems aimed at both reducing the transmittance levels of opaque surfaces to be lower than the maximum thresholds envisaged for buildings subject to energy requalification (in Brescia, equal to $0.28 \mathrm{~W} / \mathrm{m}^{2} \mathrm{~K}$ for vertical structures and $0.24 \mathrm{~W} / \mathrm{m}^{2} \mathrm{~K}$ for inclined structures or roofing) [41], as well as keeping the total thickness of the AdESA system within the limit of $25 \mathrm{~cm}$, which is the maximum thickness of the thermal layer envisaged by the Italian Standard to allow for derogation from distances between buildings required by the codes [42].

In order to design the intervention, the stratigraphy of the existing walls and of the additional wooden layers on the roof and along the short side of the buildings was taken into account. To improve the design, different solutions were evaluated, considering different types of insulating material and thicknesses, to obtain a homogeneous thermal transmittance. The value of transmittance, in addition to influencing the thermal dispersion, also played a pivotal role in the definition of comfort for users by maintaining the internal surfaces at a similar temperature in all directions.

The final energy intervention consisted of an additional layer of the AdESA system to be superimposed on the structural shell. The energy layer was composed of: a 10-centimeter thick layer of PIR (polyisocyanurate) insulation panels on the roof, with an additional sloped layer to correct the water runoff problems; an 8-centimeter-thick layer of EPS insulation panels along the short side of the building corresponding to the CLT panels, and new sliding doors and windows with electro-colored thermal break aluminum frame and double-glazing inside the steel frames; a 10-centimeter-thick layer of EPS insulation panels along the longitudinal side of the building, covering the existing precast panels. A thin layer of plasterboards was interposed between the EPS and CLT panels along the short sides for fire protection (class A1 for reaction to fire). All the walls were finished with painted plaster.

The results obtained for the considered energy intervention, estimated through dynamic simulations, are shown in Figure 19, in terms of monthly heating and cooling demands, and in Table 3 in terms of transmittance. The annual energy savings for the heating is equal to $50.51 \%$ with respect to the as-is situation, with a peak thermal load of $26 \mathrm{~kW}$ and an annual thermal load of about $31,000 \mathrm{kWh}$ [16].

Table 3. Results of the dynamic analyses for the energy intervention (AdESA 2019).

\begin{tabular}{cccc}
\hline & Insulation System & $\begin{array}{c}\text { Transmittance } \\
{\left[\mathbf{W} / \mathbf{m}^{2} \mathbf{K}\right]}\end{array}$ & $\begin{array}{c}\text { MaxTransmittance } \\
{\left[\mathbf{W} / \mathbf{m}^{2} \mathbf{K}\right]}\end{array}$ \\
\hline $\begin{array}{c}\text { Transversal short walls } \\
\text { (North and South) } \\
\begin{array}{c}\text { Longitudinal long walls } \\
\text { (East and West) } \\
\text { Roof }\end{array}\end{array}$ & CLT 10 cm + EPS $8 \mathrm{~cm}$ & 0.24 & 0.28 \\
& EPS $10 \mathrm{~cm}$ & 0.25 & 0.28 \\
\hline
\end{tabular}



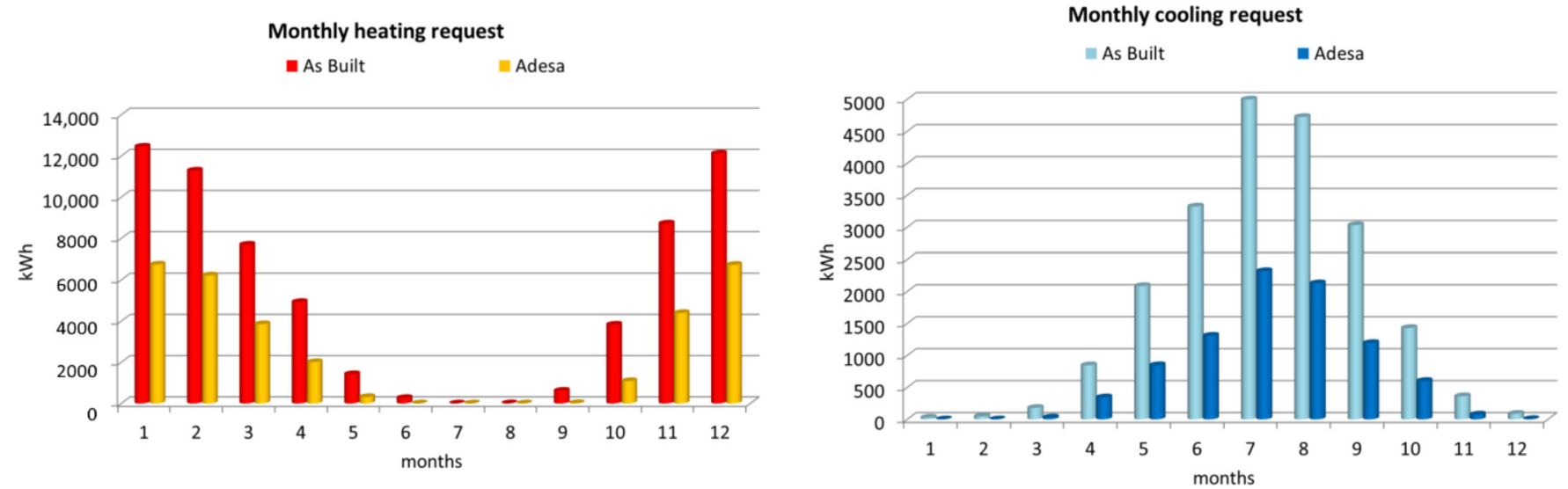

Figure 19. Energy performance before and after the energy intervention.

\subsubsection{Architectural Intervention}

The gymnasium was painted white along the north and west sides and painted red along the south and east sides. The new window and door frames were also painted red, as the longitudinal elements located at the top and bottom of the facades, defining two horizontal red lines (Figure 20).

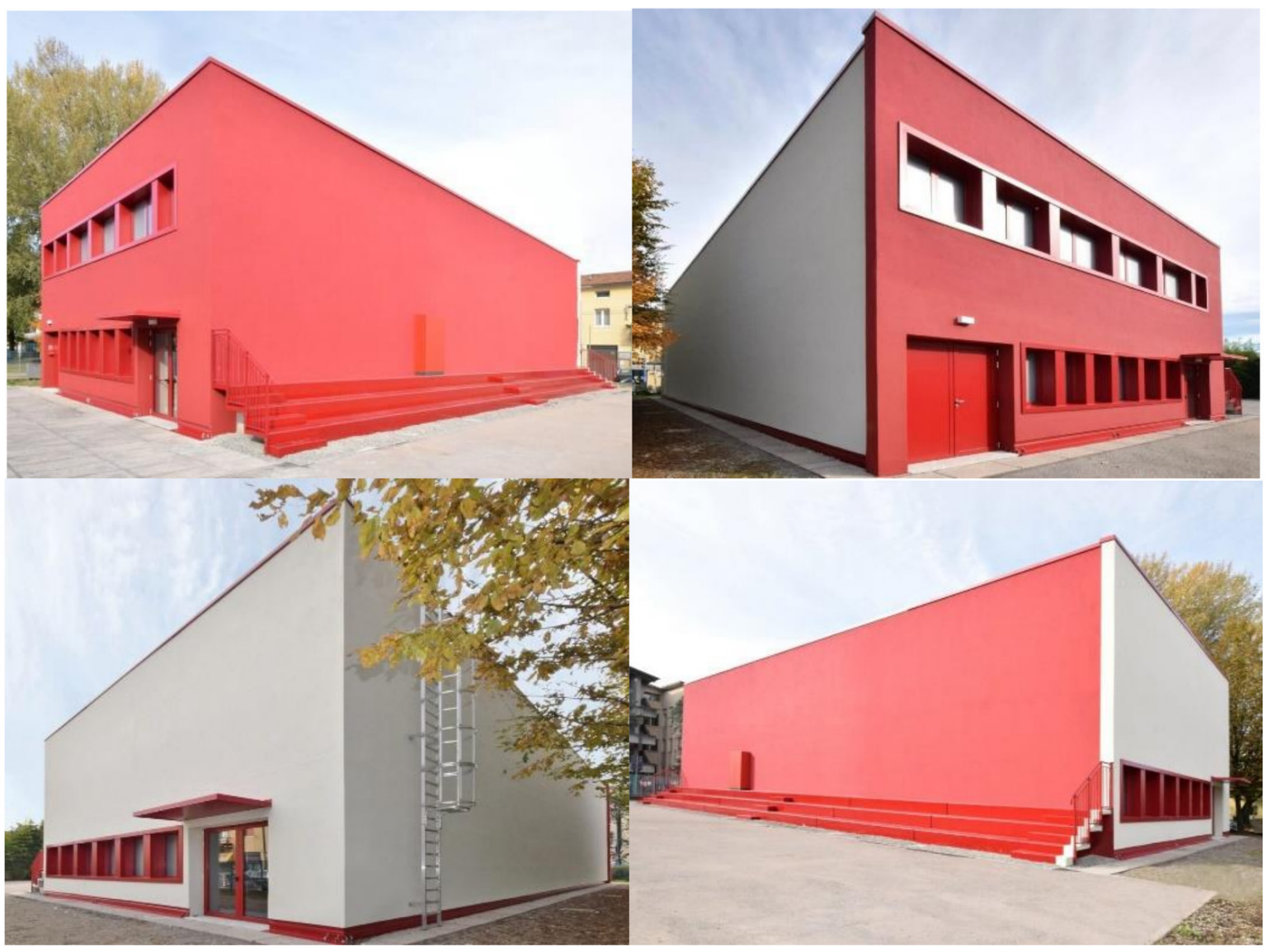

Figure 20. Views of the gym hall after the AdESA system.

The architectural intervention also included the redevelopment of the outdoor spaces by introducing a multi-sports field in the paved area, $\mathrm{RC}$ bleachers along the longitudinal wall of the gym hall, next to the playing field, and the landscaping of the green areas. 
The new bleachers define a fillet element, harmonizing the retrofitted building and the outdoor spaces, which fosters the gathering of the audience at sports events, thereby promoting sociability at the neighborhood level and nurturing the residents' affection for the place. Enabling a "building to become a place" was considered a further pivotal goal of the retrofit action, emphasizing the concept that the space between buildings, not only the buildings themselves, must be reckoned with in any credible holistic retrofit action in order to foster urban regeneration.

AdESA is an important part of a long process of study and research carried out on a European scale (see [43]), and the survey of the major urban transformations conducted over the last three decades has shown that buildings are not sufficient in themselves but enter into collaboration with each other and with the space they enclose, to build a truly shareable and truly social city.

In this scenario, a multi-sports field (basketball and five-a-side football) will soon be completed (Figure 21), a small example of attention to detail that demonstrates how AdESA's objectives encompass not only the "care" for buildings but also that required for places and their inhabitants.

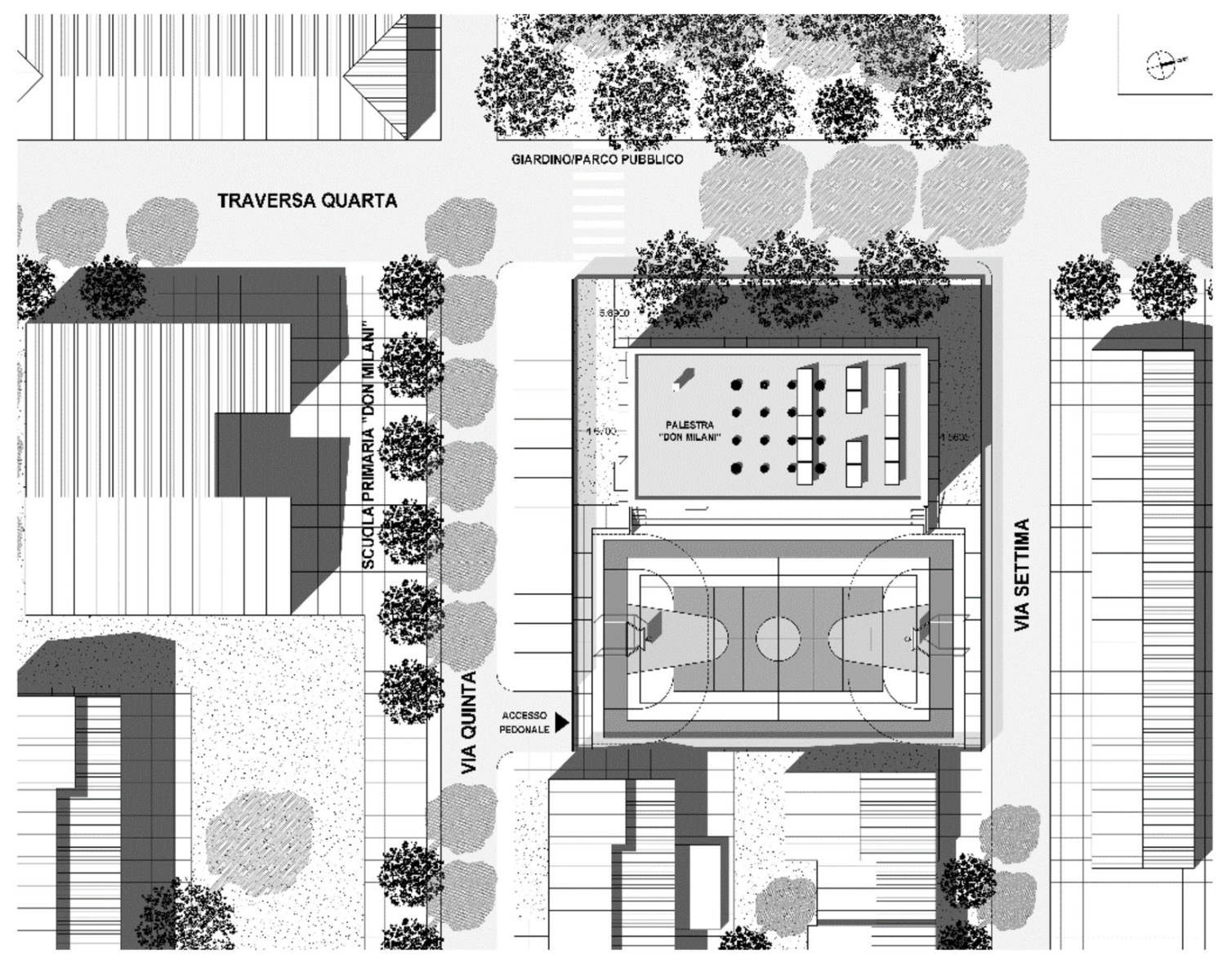

Figure 21. The refurbishment of the outdoor playground (under completion).

\section{Concluding Remarks}

The European goal of reaching carbon neutrality by 2050 has fostered the research of new sustainable solutions to renovate the existing building stock. In this paper, a holistic retrofit technique for the integrated renovation of the existing buildings is presented. The AdESA system is conceived in full compliance with the principles of life cycle thinking to pursuit eco-efficiency, resilience, and safety throughout buildings' life cycles, maximizing performances while minimizing impacts and costs. The solution enables structural, energy, 
and architectural renovation by implementing different layers, depending on the actual building needs, and can be easily adapted to different seismic and climatic zones.

In the paper, the AdESA system is first described, considering a multidisciplinary approach. From the structural point of view, the system is conceived as a shell made of cross-laminated timber (CLT) panels, spanning either vertically or horizontally. Connections between several panels, between the panels and the existing building, and with the foundation have been specifically studied to be either dissipative or over-resistant. From an energy point of view, different thermal insulation materials may be adopted for the upgrading of the energy performances and they may be coupled with additional retrofit measures. Finally, from an architectural point of view, the AdESA system may be located in close proximity to or at a certain distance from the building, allowing for possible building reshaping; in addition, different cladding systems may be adopted to obtain different esthetic finishes.

As a case study, the application of the AdESA system for the retrofit of a gym hall was presented. For this project, carried out in 2020, macro-prefabrication was adopted for the CLT panels, which were produced in the factory and merely connected to the existing building and with the steel frames on site. The assemblage and connection of the wooden panels required about 2 days of work, assuming a team of 4 people and a lightweight crane (Figure 15). The assemblage of the whole AdESA system required 4-5 months, excluding the stop in work due to the COVID-19 pandemic. The total cost of the renovation (including the layered energy and structural shell, the architectural finishes, construction site costs, preliminary works, contingencies, VAT, but excluding technical expenses) was about $390 \mathrm{EUR} / \mathrm{m}^{2}$ (euros per square meter of shell surface); as for the cost breakdown: $30 \%$ of the total cost is related to the structural retrofit, $30 \%$ to the energy amelioration measures, and $40 \%$ to other construction costs.

The application of the AdESA system to the gym hall allowed shifting the structure from a highly seismically vulnerable building to a code-conforming building (i.e., from a seismic class F to seismic class A building, with reference to the Italian Standards), solving all the major seismic vulnerabilities of the building. From an energy point of view, in winter conditions, the annual thermal load was reduced from $63,338 \mathrm{kWh}$ to $31,343 \mathrm{kWh}$, while in summer conditions, it was reduced from $21,137 \mathrm{kWh}$ to $8851 \mathrm{kWh}$, with annual energy savings equal to $50.51 \%$ and $58.12 \%$, respectively (i.e., shifting from an energy class $\mathrm{E}$ to a class B, with reference to the Italian Standards). From an architectural point of view, the building was renovated both at the building and at the urban scale.

The application of the AdESA system to the gym hall may be considered one of the first holistic retrofit techniques completely inspired by LCT principles. The application of the proposed system to a real case study also allowed us to face actual construction issues, such as the need to account for the tolerances of the connecting system, and to define new strategies for the applications. Following this experience, partial re-engineering of the solution is currently in progress and the updated version of the AdESA system is expected to be applied to a traditional residential building by the end of the year.

Author Contributions: J.Z., structural engineering-data curation, formal analysis, investigation, methodology, validation, visualization, writing-original draft, writing—review and editing; S.C., structural engineering - data curation, formal analysis, investigation, methodology, validation, visualization, writing — original draft, writing—review and editing; A.M., structural engineeringconceptualization, data curation, formal analysis, funding acquisition, investigation, methodology, project administration, supervision, validation, visualization, writing-original draft, writingreview and editing; A.B., structural engineering-data curation, formal analysis, investigation, methodology, validation, writing — review and editing; C.P., structural engineering-conceptualization, data curation, formal analysis, funding acquisition, investigation, methodology, validation, visualization, writing — original draft, writing—review and editing; E.G., structural engineeringconceptualization, data curation, formal analysis, investigation, methodology, supervision, validation, writing-review and editing; P.R., structural engineering-data curation, formal analysis, investigation, methodology, supervision, validation, writing — review and editing; B.A., architecture- 
conceptualization, data curation, formal analysis, funding acquisition, investigation, methodology, project administration, supervision, validation, visualization, writing — original draft, writing review and editing; G.B., energy engineering-data curation, formal analysis, investigation, methodology, supervision, validation, visualization, writing—original draft, writing—review and editing; A.L.M., production process-funding acquisition, investigation, methodology, project administration, supervision, validation, writing-review and editing. All authors have read and agreed to the published version of the manuscript.

Funding: This research was funded by Regione Lombardia within the framework "Smart Living".

Institutional Review Board Statement: Not applicable.

Informed Consent Statement: Not applicable.

Data Availability Statement: Not applicable.

Acknowledgments: The present work has been partly developed in the Industrial Projects "AdESA, a new system for the Energy, Seismic and Architectural integrated retrofit of existing buildings", financed by the "Smart Living" Lombardy Regional Fund. The system was developed within a consortium of Italian research and industrial partners with complementary competencies: Marlegno s.r.l., a leading company in the wood construction sector, Harpaceas s.r.l., a leading company for the diffusion of BIM in the construction sector, Edilmatic s.r.l., a leading company in the field of anchoring systems for prefabricated elements, and the Universities of Bergamo and Brescia, contributing with their expertise in the integrated deep renovation of existing buildings. The authors greatly acknowledge all the partners who collaborated in the development of the AdESA project:

o University of Bergamo-energy group: G. Franchini

o University of Brescia-structure group: M. Preti, V. Bolis;-architecture group: B. Badiani, M. Botti, M. Battisti, A. Soci, R. Marmori, eng. A. Ghirardi, M. Flandina

o MARLEGNO S.r.l.: S. Carminati, K. Trovenzi

o EDILMATIC S.r.l.: F. Luitprandi, F. Magnani, R. Bonini

o HARPACEAS S.r.l.: P. Odorizzi, A. Alli, O. Mariani, G. Svaluto

o $\quad$ COMUNE DI BRESCIA: M. Azzini, C. Lazzaroni, A. Caporali

Conflicts of Interest: The authors declare no conflict of interest.

\section{References}

1. European Commission. The European Construction Sector: A Global Partner. March 2016 G.U. 6/11/2017-Gazzetta Ufficiale Della Repubblica Italiana 6/11/2017. Piano D'azione Nazionale Sul Green Public Procurement (PANGPP). Criteri Ambientali Minimi per L'affidamento di Servizi di Progettazione e Lavori Per la Nuova Costruzione, Ristrutturazione e Manutenzione di Edifici Pubblici. 2016. Available online: https://www.gazzettaufficiale.it/eli/id/2017/11/06/17A07439/sg (accessed on 11 October 2021).

2. Marini, A.; Negro, P.; Passoni, C.; Riva, P.; Romano, E.; Taucer, F. Technology Options for Earthquake Resistant, Eco-Efficient Buildings in Europe: Research Needs; JRC Report EUR 26497 EN.; Report EUR 26497 EN. JRC87425; Publications Office of the European Union: Luxembourg, 2014; ISBN 978-92-79-35424-3. [CrossRef]

3. Vitali Roscini, A.; Rapf, O.; Kockat, J. On the Way to a CLIMATE-NEUTRAL EUROPE. Contributions from the Building Sector to a Strengthened 2030 Climate Target; BPIE Report. Brussels, Belgium, 2020. Available online: https://www.bpie.eu/wp-content/ uploads/2020/12/On-the-way-to-a-climate-neutral-Europe-_Final.pdf (accessed on 11 October 2021).

4. Gantner, J.; Wittstock, B.; Lenz, K.; Fischer, M.; Sedlbauer, K. EeBGuide Guidance Document-Part B: Buildings. Operational Guidance for Life Cycle Assessment Studies of the Energy Efficient Building Initiative, FRAUNHOFER. 2012. Available online: https:/ / publica.fraunhofer.de/eprints/urn_nbn_de_0011-n-3500005.pdf (accessed on 11 October 2021).

5. Belleri, A.; Marini, A. Does seismic risk affect the environmental impact of existing buildings? Energy Build. 2016, 110, 149-158. [CrossRef]

6. Caverzan, A.; Lamperti Tornaghi, M.; Negro, P. Proceedings of SAFESUST Workshop: A Roadmap for the Improvement of Earthquake Resistance and Eco-Efficiency of Existing Buildings and Cities; Publications Office of the European Union: Luxembourg, 2016; ISBN 978-92-79-62618-0. [CrossRef]

7. UNEP/SETAC, Greening the Economy through Life Cycle Thinking. 2012. Available online: https://www.lifecycleinitiative.org/ wp-content/uploads/2013/03/2012_LCI_10_years_28.3.13.pdf (accessed on 11 October 2021).

8. EN 15978:2011. Sustainability of Construction Works-Assessment of Environmental Performance of Buildings-Calculation Method; CEN: Belgium, Brussels, 2011.

9. Passoni, C.; Marini, A.; Belleri, A.; Menna, C. Redefining the concept of sustainable renovation of buildings: State of the art and an LCT-based design framework. Sustain. Cities Soc. 2021, 64, 102519. [CrossRef] 
10. Dodd, N.; Donatello, S.; Cordella, M. Level(s)-A Common EU Framework of Core Sustainability Indicators for Office and Residential Buildings, User Manual 1: Introduction to the Level(s) Common Framework (Publication Version 1.1). 2021. Available online: https://susproc.jrc.ec.europa.eu/product-bureau/sites/default/files/2020-10/20201013\%20New\%20Level(s) \%20documentation_1\%20Introduction_Publication\%20v1-0.pdf (accessed on 11 October 2021).

11. COMMISSION OF THE EUROPEAN COMMUNITIES, COM(2003)302. Communication EU Integrated Product Policy-Building on Environmental Life-Cycle Thinking. 2003. Available online: https:/ / eur-lex.europa.eu/LexUriServ/LexUriServ.do?uri=COM: 2003:0302:FIN:en:PDF (accessed on 11 October 2021).

12. BPIE (Building Performance Institute Europe). Europe's Buildings under the Microscope: A Country-by-Country Review of the Energy Performance of the Buildings, Brussel, 2011. Available online: http:/ / www.bpie.eu (accessed on 11 October 2021).

13. La Greca, P.; Margani, G. Seismic and energy renovation measures for sustainable cities: A critical analysis of the Italian scenario. Sustainability 2018, 10, 254. [CrossRef]

14. NTC. Aggiornamento Dell "Norme Tecniche Per le Costruzioni". D.M. 17 Gennaio 2018. Available online: https://www. gazzettaufficiale.it/eli/gu/2018/02/20/42/so/8/sg/pdf (accessed on 11 October 2021).

15. DPR 412/93-DPR n 412 Del 26/8/1993 e Successivi Aggiornamenti Fino al 31/10/2009-“Regolamento Recante Norme Per la Progettazione, L'installazione, L'esercizio e la Manutenzione Degli Impianti Termici Degli Edifici ai Fini del Contenimento Dei Consumi di Energia, in Attuazione Dell'Art. 4, Comma 4, Della L. 9 Gennaio 1991, n.10". Available online: https:/ /www. bosettiegatti.eu/info/norme/statali/1993_0412.htm (accessed on 11 October 2021).

16. AdESA (Adeguamento Energetico Sismico ed Architettonico). Caso Studio Palestra Della Scuola Primaria "Don Milani", Traversa IV-Villaggio Badia n.12; Final Report. Project ID n. 379259; Smart Living Project; Regione Lombardia: Brescia, Italy, 2019.

17. Green Tech Cluster Styria GmbH. Leading Technologies from the Green Tech Cluster, Austria. 2017. Available online: www. greentech.at (accessed on 11 October 2021).

18. Sustersic, I.; Dujic, B. Seismic strengthening of existing concrete and masonry buildings with crosslam timber panels. In Materials and Joints in Timber Structures; Aicher, S., Reinhardt, H.W., Garrecht, H., Eds.; Springer: Dordrecht, The Netherlands, 2014; Volume 9. [CrossRef]

19. Della Mora, T.; Righi, A.; Peron, F.; Romagnoni, P. Functional, energy and seismic retrofitting in existing building: An innovative system based on xlam technology. Energy Procedia 2015, 82, 486-492. [CrossRef]

20. Cassol, D.; Giongo, I.; Piazza, M. Numerical Study on Seismic Retrofit of URM Walls Using Timber Panels. In Proceedings of the 8 th ECCOMAS Thematic Conference on Computational Methods in Structural Dynamics and Earthquake Engineering, Athens, Greece, 27 June 2021.

21. Passoni, C.; Guo, J.; Christopoulos, C.; Marini, A.; Riva, P. Design of dissipative and elastic high-strength exoskeleton solutions for sustainable seismic upgrades of existing RC buildings. Eng. Struct. 2020, 221, 111057. [CrossRef]

22. Labò, S..; Passoni, C.; Marini, A.; Belleri, A. Design of diagrid exoskeletons for the retrofit of existing RC buildings. Eng. Struct. 2020, 220, 110899. [CrossRef]

23. Manfredi, V.; Masi, A. Seismic strengthening and energy efficiency: Towards and integrated approach for the rehabilitation of existing RC buildings. Buildings 2018, 8, 36. [CrossRef]

24. Di Lorenzo, G.; Colacurcio, E.; Di Filippo, A.; Formisano, A.; Massimilla, A.; Landolfo, R. State-of-the-art on steel exoskeletons for seismic retrofit of existing RC buildings. Ing. Sismica 2020, 37, 50.

25. Reggio, A.; Restuccia, L.; Menardi, A.; Corrado, V.; Ferro, G.A. Integrated, sustainable, low-impact retrofitting through exoskeleton structures: A case study. In Proceedings of the XVIII CONVEGNO ANIDIS, Ascoli Piceno, Italy, 15-19 September 2019.

26. Takeuchi, T.; Yasuda, K.; Iwata, M. Seismic retrofitting using energy dissipation façades. In Proceedings of the ATC \& SEI Conference on Improving the Seismic Performance of Existing Buildings and Other Structures, San Francisco, CA, USA, 9-11 December 2009; pp. 1000-1009.

27. Marini, A.; Passoni, C.; Belleri, A.; Feroldi, F.; Preti, M.; Metelli, G.; Giuriani, E.; Riva, P.; Plizzari, G. Combining seismic retrofit with energy refurbishment for the sustainable renovation of RC buildings: A proof of concept. Eur. J. Environ. Civ. Eng. 2017. [CrossRef]

28. Marini, A.; Belleri, A.; Passoni, C.; Feroldi, F.; Giuriani, E. In-plane capacity of existing Post-WWII beam-and-block floor systems. Bull. Earthq. Eng. 2021. submitted.

29. Giuriani, E.; Marini, A. Wooden roof box structure for the anti-seismic strengthening of historic buildings. Int. J. Archit. Herit. 2008, 2, 226-246. [CrossRef]

30. Carattin, E.; Franz, M.; Luciano, S. Materiali Isolanti-Nuove Tendenze in Architettura. IUAV Venezia, 2008. Available online: http:/ / www.iuav.it/SISTEMA-DE/Archivio-d/approfondi/materiali-/Materiali_Isolanti.pdf (accessed on 11 October 2021).

31. Biswas, K.; Patel, T.; Shrestha, S.; Smith, D.; Desjarlais, A. Whole building retrofit using vacuum insulation panels and energy performance analysis. Energy Build. 2019, 203, 109430. [CrossRef]

32. Ruben, B.; Jelle, B.P.; Gustavsen, A. Aerogel insulation for building applications: A state-of-the-art review. Energy Build. 2011, 43, 761-769.

33. Abate, M. Strategies for the Architectural Redevelopment of the Built Environment with Anti-Seismic Structural Enclosure and for Energy Retrofitting. Master Thesis, Università degli Studi di Brescia, Brescia, Italy, 2019. Supervisors: Barbara Angi, Alessandra Marini. 
34. MidasGen 2020 v.1.1. Copyright @ SINCE 1989 MIDAS Information Technology Co., Ltd. Available online: https:/ / www.cspfea. net/prodotti/midas-gen/ (accessed on 11 October 2021).

35. Belleri, A.; Cornali, F.; Passoni, C.; Marini, A.; Riva, P. Evaluation of out-of-plane seismic performance of column-to-column precast concrete cladding panels in one-storey industrial buildings. Earthq. Eng. Struct. Dyn. 2017, 47, 397-417. [CrossRef]

36. McDowell, T.; Bradley, D.E.; Hiller, M.; Lam, J.; Merk, J.; Keilholz, W. TRNSYS 18: The Continued Evolution of the Software. In Proceedings of the 15th IBPSA Conference, San Francisco, CA, USA, 7-9 August 2017.

37. Murray, M.C.; Finlayson, N.; Kummert, M.; Macbeth, J. Live Energy TRNSYS-TRNSYS Simulation within Google SketchUp; Eleventh International IBPSA Conference: Glasgow, Scotland, 2009; pp. 1389-1396.

38. Remund, J.; Müller, S.; Kunz, S.; Schilter, C. Meteonorm Handbook Part. II: Theory. 2012. Available online: https:/ / www.energiehaus es/wp-content/uploads/2015/06/manual-usuario-part-2-meteonorm.pdf (accessed on 11 October 2021).

39. Gelfi, P.; Giuriani, E.; Marini, A. Stud Shear Connection Design for Composite Concrete Slab and Wood Beams. J. Struct. Eng. 2002, 128, 1544-1550. [CrossRef]

40. Iervolino, I.; Galasso, C.; Cosenza, E. REXEL: Computer aided record selection for codebased seismic structural analysis. Bull. Earthq. Eng. 2010, 8, 339-362. [CrossRef]

41. D.d.u.o. 12 gennaio 2017-n. 176-Aggiornamento Delle Disposizioni in Merito Alla Disciplina Per L'efficienza Energetica Degli Edifici e al Relativo Attestato Di Prestazione Energetica in Sostituzione Delle Disposizioni Approvate Con i Decreti n. $6480 / 2015$ e n. 224/2016. Available online: https: / / www.anit.it/norma/regione-lombardia-testo-unico-sullefficienza-energetica-degliedifici/ (accessed on 11 October 2021).

42. Decreto Legislativo, n. 102 del 04/07/2014. Available online: http://www.energia.provincia.tn.it/binary/pat_agenzia_energia/ DLgs\%20102-2014\%20aggiornato\%20al\%20DLgs\%20141-2016.pdf (accessed on 11 October 2021).

43. Angi, B. (Ed.) Eutopia Urbanscape; Lettera Ventidue: Siracusa, Italy, 2016; ISBN 9788862421904. 